\title{
Forward Looking Loan Provisions: Credit Supply and Risk-Taking
}

\author{
Bernardo Morais Gaizka Ormazabal \\ José-Luis Peydró Mónica Roa Miguel Sarmiento*
}

\begin{abstract}
We show corporate-level real, financial, and (bank) risk-taking effects associated with calculating loan provisions based on expected - rather than incurred-credit losses. For identification, we exploit unique features of a Colombian reform and supervisory, matched loan-level data. The regulatory change induces a dramatic increase in provisions. Banks tighten all new lending conditions, adversely affecting borrowing-firms, with stronger effects for risky-firms. Moreover, to minimize provisioning, more affected (less-capitalized) banks cut credit supply to risky-firmsSMEs with shorter credit history, less tangible assets or more defaulted loans - but engage in "search-for-yield" within regulatory constraints and increase portfolio concentration, thereby decreasing risk diversification.
\end{abstract}

JEL codes: E31, G18, G21, G28.

Keywords: Loan provisions, IFRS9, ECL, corporate real and credit supply effects of accounting, bank risk-taking.

\footnotetext{
* This draft is from August 2020. Bernardo Morais: Federal Reserve Board, bernardo.c.morais@frb.gov; Gaizka Ormazabal: IESE Business School, GOrmazabal@iese.edu; José-Luis Peydró: Imperial College London, ICREAUPF-CREI-BarcelonaGSE, CEPR, jose.peydro@gmail.com; Mónica Roa: monicaproa@gmail.com; Miguel Sarmiento: Banco de la República Colombia, European Banking Center, nsarmipa@banrep.gov.co. We thank, Charles Calomiris, Pamela Cardozo, Ángel Estrada, Jorge Galán, Martha López, Javier Mencía, Daniel Osorio, Carlos Pérez, Hernando Vargas, Claudia Ruiz, and conference participants at the Banco de México, Federal Reserve Board, Bank of Spain, IFABS in Angers, Bank of International Settlements, Ryerson University, IBEFA, and Banco de la República for helpful comments. Peydró acknowledges financial support from the European Research Council (Grant No. 648398) and from the PGC2018-102133-B-I00 (MCIU/AEI/FEDER, UE) grant and the Spanish Ministry of Economy and Competitiveness, through the Severo Ochoa Programme for Centres of Excellence in R\&D (SEV-20150563). Gaizka Ormazabal acknowledges financial contributions from the Spanish Ministry of Economics, Industry and Competitiveness, grant ECO2015-63711-P, and from the "Cátedra de Dirección de Instituciones Financieras y Gobierno Corporativo del Grupo Santander". The views in this paper are solely the reflective of the authors' and should not be interpreted as reflecting the views of the Board of Governors of the Federal Reserve System or of any other person associated with the Federal Reserve System, or the Banco de la República Colombia.
} 


\section{Introduction}

In the aftermath of the 2008 financial crisis, the traditional method used to measure impairment allowances based on incurred credit losses (ICL) is gradually being replaced by the alternative approach of building provisions based on expected credit losses (ECL). ${ }^{1}$ The move towards ECL provisioning, responds to the widespread perception that the ICL model resulted in insufficient and untimely provisions, thereby exacerbating the economic cycle (Acharya and Ryan, 2016; Bischof, Laux, and Leuz, 2019; Huizinga and Laeven, 2019). While less acute, the concern that loan provisioning induced procyclicality (and thus exacerbated booms and recessions) was already present before the 2008 financial crisis (see, for example, Laeven and Majnoni, 2003). The switch from ICL to ECL is considered to be one of the major developments in the recent history of the banking industry. For example, the American Banks Association described this regulatory change as "the most sweeping change to bank accounting ever". ${ }^{2}$ Nonetheless, to date there is a paucity of empirical evidence on the potential economic effects of this rule change.

In this paper, we fill this gap by studying a regulation that was pioneer in the implementation of the ECL model. After the Latin American financial crisis of the late 90's, Colombia engaged in a major reform of the system used by banks to assess credit risk. The new system — known as Sistema de Administración de Riesgo de Crédito ("SARC")—included a provisioning scheme remarkably similar to the ECL model in IFRS9 and CECL (i.e., the United States' standard ASU 2016-13). ${ }^{3}$ Critically, SARC mandated the estimation of expected losses based on three key ex-ante characteristics statistically associated with ex-post default: borrower size, loan collateralization, and historical delinquency.

\footnotetext{
${ }^{1}$ The IASB introduced the ECL in the accounting standard IFRS9, which was implemented in 2018, in more than 120 countries, whereas in the United States the FASB did so in ASU 2016-13 (also known as "CECL"). The U.S. standard was planned to be implemented in 2020, but it has been delayed due to the Covid-19 crisis.

${ }^{2}$ See https://www.aba.com/advocacy/our-issues/cecl-implementation-challenges. This view is also shared by other prominent institutions such as the European Banking Association and the Global Public Policy Committee (representing the six largest accounting networks). For example, the Global Public Policy Committee states: "For many banks, the adoption of expected credit loss accounting will be the most momentous accounting change they have ever experienced" (see https://www2.deloitte.com/bd/en/pages/financial-services/articles/2016-gppc-theimplementation-of-ifrs9- impairment-requirements-by-banks.html).

${ }^{3}$ SARC was introduced gradually and its content was not restricted to the quantification of credit risk (it also contained guidance on policies and processes (including responsibility definitions)). However, the methodology to quantify credit losses, the "Modelo de Referencia de Cartera Commercial" (MRC), entered into force in July 1t, 2007. Therefore, our analysis is conducted around this date. For simplicity, throughout the paper we refer to the change in the provisioning scheme as "SARC", as the MRC was developed in the context of SARC.
} 
Several considerations suggest that SARC is especially suited to empirically identify the economic consequences of the ECL model. First, the Colombian setting allows us to exploit a combination of proprietary datasets whose granularity offers unique opportunities for the empirical identification of the effect of the ECL model on the supply of credit and on the real economy. Second, the identification of the effect of SARC is enhanced by plausibly exogenous crosssectional variation stemming from the pre-existing legal framework (the provisioning scheme was defined based on arbitrary size thresholds introduced by Law 905 of 2004). ${ }^{4}$ Third, unlike recent provisioning rules, the Colombian provisioning scheme entered into effect before the global financial crisis that followed the collapse of Lehman Brothers in mid-September 2008. As shown in Figure A1, during the time window of our analysis Colombia experienced strong economic growth (more than 5\% in all periods), decreasing unemployment, and a rising stock market (the effect of the 2008 financial crisis was not noticeable until later on, in 2009).

Whether ECL provisioning improves the efficiency of the banking system is an open empirical question. On the one hand, switching from the ICL model to the ECL model may result in more timely provisions, addressing the concern that under ICL, provisioning was "too little, too late" (e.g., Gaston and Song, 2014; Bischof, Laux, and Leuz, 2019). ${ }^{5}$ On the other hand, the ECL model could also have adverse consequences in the supply of credit to firms and, thereby, in the economy. Higher ex-ante provisioning could increase the cost of lending, thereby inducing banks to tighten their lending standards, especially for ex-ante riskier borrowers. ${ }^{6}$ Moreover, as explained by Freixas and Rochet (2008), higher loan provisioning may decrease bank profits and capital, thus increasing risk-taking incentives.

\footnotetext{
${ }^{4}$ Following the Law 905 of 2004, SARC classifies commercial firms into three categories - Small, Medium, and Large (Pequeña, Media and Grande, respectively) - depending on the value of their assets.

${ }^{5}$ More specifically, the concern is that, at the beginning of the global financial crisis of 2008 , the provisioned amounts (loan loss allowances) under the incurred loss model were not sufficient to face the downturn. As such, banks had to create additional provisions, which resulted in lower earnings (provisions are expensed in the profit and loss account) just at the time when the entities could not recognize the interest income from non-performing loans. The resulting decrease in income reduced the banks' regulatory capital during the economic downturn, leading to severe funding and capital pressures, and eventually forcing many banks to deleverage. A number of banks did so by selling noncore business lines and reducing the amount of risk-weighted assets (RWA). The reduction of RWA was executed, to a large extent, by restricting new lending, thereby generating negative externalities.

${ }^{6}$ The possibility that provisioning under expected losses could lead to credit tightening, amid the COVID-19 pandemic, was the main reason for the delay in the implementation of the CECL in the U.S. (FDIC, 2020). Similarly, the IFRS loosened the regulation concerning the estimation of ECL under IFRS9 (IFRS, 2020).
} 
Our sample includes comprehensive loan-level data from the universe of commercial loans granted to banks operating in Colombia, data that we complement with mandatory accounting information from the corresponding lending banks and borrowing firms. We start by analyzing the evolution of provisions within a window of one year around the implementation of the change in the provisioning scheme (i.e., 2006Q2 to 2008Q2). We observe a doubling in the overall level of provisions in the quarters immediately before and immediately after the introduction of the regulation (in 2007Q2 the average provision was of around 1.7 percent, whereas in 2007Q3 it jumped to 3.6 percent). This stark increase in provisions cannot be explained by a deterioration in economic conditions, as the Colombian economy was booming around the implementation of the new provisioning scheme. ${ }^{7}$ Moreover, the rise in the level of provisions exhibits substantial heterogeneity reflecting the specific features of the regulation. Consistent with the key regulatory parameters dictating the level of provisioning, the increase in provisions is concentrated among loans granted to smaller borrowers, non-collateralized loans, and loans extended to borrowers operating in riskier sectors.

We then gauge the impact of the new provisioning scheme on credit supply, using a difference-in-difference approach to exploit the key regulatory drivers of the level of provisioning imposed by SARC. Under the new regime, the value of loans extended to smaller firms declines 16 percent relative to the loans extended to larger firms. In parallel, the interest rate paid by smaller firms is 0.5 percentage points larger than that paid by larger firms, and the maturity of loans granted to smaller firms declines by roughly 6 percent relative to that of larger firms. Also consistent with lenders' minimizing the increase in provisions induced by SARC, we find that the tightening of credit to smaller borrowers is concentrated among firms operating in sectors with a lower amount of tangible assets (tangible assets are easier to use as collateral). More concretely, a one standard deviation decrease in the tangibility of a sector is associated with a reduction of loan value of around 13 percent. Finally, we observe that smaller borrowers with defaulted loans (i.e., loans more than 90 days in arrears) exhibit significantly tighter credit conditions under the new accounting regime. After the change in regulation the value of loans given to defaulting borrowers

\footnotetext{
${ }^{7}$ During the 2006Q2-2008Q2 period, the economy was booming as indicated by all major economic indicators displayed in Figure A1. Furthermore, the IMF's assessment of the Colombian economy (Article IV, published in December 2008) stated that "Sound economic policies have contributed to strong economic performance in recent years. This performance has been accompanied by a significant reduction in macroeconomic vulnerabilities" (IMF, 2008).
} 
(i.e., a subset with a high proportion of "zombie" firms) declines roughly 60 percent, relative to those of non-defaulting borrowers.

We also find evidence consistent with the notion that the new provisioning scheme significantly affects the real activity of smaller firms (i.e., the borrowers requiring higher provisions according to the new provisioning scheme). We observe that the liabilities of smaller firms decline by 30 percent relative to those of large firms (suggesting that these firms could not substitute bank lending for other sources of financing). Furthermore, after the implementation of the new provisioning scheme, the level of smaller firms' assets and sales (relative to those of larger borrowers) declines by 20 and 12 percent, respectively. Confirming that the worsening in smaller firms' real outcomes is associated with a contraction of credit, our firm-level tests show a significant decrease in the value of smaller firms' aggregate loans after the implementation of the new provisioning scheme.

To shed additional light on the effect of the reform on risk-taking, our final set of tests explores the impact of the new rules across lenders. We focus on cross-sectional variation in banks' insolvency risk, as the effect of the reform is likely to be more pronounced among banks with less ex-ante capital (these banks have less capacity to take on higher provisions as they are closer to minimum capital requirements and provisions affect the income statement and thus shareholder equity). First, we find that, under SARC, "weaker" banks (i.e., banks with higher insolvency risk) are more likely to avoid borrowers that require higher regulatory provisions (i.e., smaller borrowers and borrowers operating in sectors with higher default rates). Within the subsample of riskier sectors, a one standard deviation increase in insolvency risk is associated with 7.8 percent decline in credit supply.

Second, we partition the sample based on borrowers' ex-ante loan interest rates and find contrasting results. For the subsample of low-yield borrowers, we observe that, under SARC, weaker banks tighten the credit to smaller borrowers (a one standard deviation increase in insolvency risk is associated with 10.8 percent lower loan values). However, we observe the opposite result in the subsample of high-yield borrowers. Under SARC, weaker banks provide more credit to borrowers with higher yields (a one standard deviation increase in insolvency risk is associated with 20 percent larger loan values). Tellingly, we find that such increase in credit is accompanied by a substantial increase in interest rates. Taken together, this evidence suggests that 
SARC induces weaker lenders to engage in "search-for-yield" within the constraints of the regulation in an attempt to make up for the lower profitability induced by the increase in provisions.

Third, we examine whether SARC resulted in a reshaping of banks' loan portfolios. Regarding the composition of the banks' loan portfolios, we find that under SARC, more affected banks (i.e., weaker banks) end up with smaller portfolios of loans (a one standard deviation increase in insolvency risk is associated with a 5 percent decrease in the aggregated value of loans in the portfolio). Furthermore, we find that weaker banks increase relatively more their credit to borrowers with a longer credit relation with the bank. We also observe that the portfolio of weaker banks contains loans granted to borrowers in sectors with more tangible assets and lower default rates. Consistent with our prior tests, these results suggest that weaker banks reduce credit and engage in lending behavior that minimizes the increase in provisions induced by SARC.

However, we also find that, under SARC, weaker banks increase the concentration of their portfolio of loans (a one standard deviation increase in insolvency risk leads to an increase in the Herfindahl index of 10 percent or more), an increase that is larger for banks with higher ex-ante exposure to smaller borrowers. In line with our prior results, this evidence suggests that the effect of SARC on bank risk-taking is nuanced. While bank portfolios become more "conservative" (i.e., smaller loan volume, well-known clients, and sectors with lower risk and more tangible assets), those portfolios are more concentrated and thus provide less risk diversification.

Taken together, our evidence suggests that the new provisioning scheme induces banks to reduce credit and charge a higher cost of capital to riskier (mainly smaller) firms, a lending behavior that translates into a slowdown of real activity among the affected borrowers. The effect is stronger among banks with less capital, which have less capacity to take on higher provisions. While these banks avoid borrowers that induce higher provisions (typically riskier borrowers), the overall effect of SARC on bank risk-taking is mixed, as banks engage in "search for yield" within the constraints of the regulation to mitigate the negative effect of higher provisions on bank profitability. Moreover, the induced lending behavior results in more concentrated (and thus less diversified) loan portfolios.

Our paper builds on prior research on the relation between bank provisioning and economic cyclicality. One stream of this research shows that, under the ICL model, banks often delay 
provisioning for bad loans, and that such delay is associated with bank behavior that induces procyclicality (Laeven and Majnoni, 2003; Beatty and Liao, 2011; Bushman and Williams, 2012 and 2015, Bischof, Laux, and Leuz, 2019; Huizinga and Laeven, 2019). More recent literature analyzes the effect of switching from the ICL model to the ECL model, whose relevance is enhanced by the recent introduction of IFRS9 around the world and the impending implementation of ASU 2016-13 in the United States. A strand of this literature studies theoretically the potential effect of the ECL on the economic cycle (Abad and Suarez, 2018; Buesa, Población and Tarancón, 2019; Mathieux, Sapra, and Zhang, 2020). Other recent papers exploit newly published data on the implementation of IFRS9 to test empirically the effect of the ECL model. López-Espinosa, Ormazabal, and Sakasai (2020) document an increase in the informativeness of LLP amounts reported under ECL (vis-à-vis those reported under ICL) when credit conditions are relatively more adverse. Using reconciliation disclosures on the day-one impact of IFRS9 in the European Union, Gaffney and McCann (2019), Ertan (2020) and Löw, Schmidt, and Thiel (2019) provide evidence consistent with IFRS9 inducing an increase in provisions and a decline in credit.

Our study adds to this research in various ways. First, our evidence on the effect of ECL provisioning provides important insights to help manage the regulatory tradeoff between economic growth (we study real effects induced by changes in credit supply) and financial stability (we study changes in banks' risk-taking behavior). Second, our setting offers new and unique opportunities for the empirical identification of the effect of ECL provisioning on the supply of credit. Third, the granularity and comprehensiveness of our combined datasets allows us to address two unexplored consequences of ECL provisioning, namely whether the credit contraction induced by the ECL model affects firms' real and financial outcomes and whether banks make up for the decrease in credit supply by engaging in "search for yield". Fourth, ours is the first paper documenting that the effect of ECL provisioning in credit supply is strong enough to reshape the characteristics of the loan portfolio of banks (e.g, loan concentration). Fifth, ours is also the first paper showing that the effect of ECL provisioning critically depends on banks' insolvency risk.

Another stream of prior research on the relation between bank provisioning and economic cyclicality studies the dynamic component of the provisioning schemes introduced as part of the macro-prudential toolkit of some countries (Agénor, and da Silva, 2016; Jiménez et al., 2017; Gómez et al., 2020). The provisioning scheme we study is fundamentally different from the 
dynamic provisions in prior studies. ${ }^{8}$ To begin, the ECL model is used to estimate specific provisions, whereas the dynamic component of the provisioning schemes is part of banks' generic loan loss provisions. More critically, when credit is higher, dynamic provisions are also higher, while the level of expected losses crucially depends on future prospects. In fact, a key issue in the debate surrounding the ECL model is the concern that, in some situations, such a provisioning scheme can exacerbate economic downturns (e.g., Abad and Suarez, 2018). Notably, in the context of the COVID-19 pandemic there is a widespread concern that a full application of the ECL model would exacerbate the crisis, a concern that has triggered a variety of responses from bank regulators and supervisors, accounting regulators, and legislators (Borio and Restoy, 2020). ${ }^{9}$ Our evidence provides empirical support for the claim that provisioning based on expected losses can contribute to the slowdown of economic activity.

In addition, our paper makes several contributions to the literature on financial intermediation. First, by showing that the accounting for loan loss provisions have important firmlevel real effects (via changes in banks' credit supply), we contribute to the literature on the effects of the financial system on the real economy (Ivashina and Scharfstein, 2010; Bolton et al., 2016; Di Maggio et al., 2017; Beck et al., 2018; Agarwal et al., 2018; Jiménez et al., 2019), a stream of research which is mainly focused on the real effects of financial crises and monetary policies, and thus rarely touches on the role of accounting rules. ${ }^{10}$ Second, our result that the effect of SARC is a function of asset collateralizability provides empirical support for theoretical models on the crucial role of collateral in the mitigation of credit risk (Stiglitz and Weiss, 1981; Rajan and Winton, 1995, Gorton and Ordoñez, 2014). ${ }^{11}$ Third, by showing that provisioning schemes can induce banks to "search for yield", our work extends the literature on the risk-taking behavior of

\footnotetext{
${ }^{8}$ It is important to mention that the dynamic component of the SARC regulation was implemented in 2010. Since July 2007, banks were mandated to only accumulate provisions under the new provisioning model based on expected losses. In 2010, the regulator established the conditions to reducing loan provisions according to the credit cycle and on bank-specific conditions, and hence making use of the dynamic component of the loan provisions.

${ }^{9}$ As explained by Borio and Restoy (2020), the authorities' response so far includes three types of initiatives: (i) allowing banks to temporarily suspend the application of the ECL model, (ii) enhancing existing arrangements so as to temporarily sterilize the effect on regulatory capital, and (iii) issuing pragmatic implementation guidance to avoid a boost in provisions. For more details, see López-Espinosa et al. (2020).

${ }^{10}$ One exception is Jiménez et al. (2017)'s study of dynamic provisioning. However, these authors do not find real effects associated to the introduction of dynamic provisioning (which is different from provisioning based on expected losses).

${ }^{11}$ While the literature provides some empirical evidence on the role of collateral in the mitigation of credit risk (e.g., Degryse and Van Cayseele, 2000; Jimenez et al., 2006; Agarwal and Hauswald, 2010), our paper sheds new light on this important issue by exploiting a major regulatory change in the accounting for loan loss provisioning.
} 
financial intermediaries (see e.g., Rajan 2005, Boyd and De Nicoló, 2005; Acharya et al., 2006; Maddaloni and Peydró, 2011, Becker and Ivashina, 2015).

The rest of the paper is organized as follows. Section 2 provides background on the regulatory reform and discusses prior literature. Section 3 describes the data and presents descriptive statistics. Section 4 analyzes the effect of the regulatory change across borrowers, including changes in the supply of credit and the corresponding consequences in firm outcomes. Section 5 analyzes the effect of the regulatory change across lenders. Section 6 concludes.

\section{Background and Prior Literature}

\subsection{Institutional Background}

The Latin American financial crisis in 1998 generated the perception that banks' credit management systems were not effective. As a response, Colombia's financial regulator, the Superintendencia Financiera de Colombia (SFC), pushed for a major reform of the risk management systems of Colombian banks. ${ }^{12}$ In particular, the SFC required banks to implement a risk management system known as Sistema de Administracion de Riesgo de Credito (henceforth we refer to the system as "SARC"). SARC was introduced through the 2002 "Circular Externa 11", which established general principles for the evaluation of credit risks. ${ }^{13}$ The new approach was aimed at addressing perceived deficiencies in risk assessment practices, including ad-hoc classification of risks and insufficient provisioning (SFC, 2013). SARC was implemented in three phases extended over several years. ${ }^{14}$

\footnotetext{
12 The Superintendencia Financiera de Colombia (SFC) was created as a result of merging the Superintendencia Bancaria de Colombia and the Superintendencia de Valores (Decree 4327 of 2005, subsequently modified by Decree 2555 of 2010, Law 1480 of 2011, and Decree 710 of 2012).

${ }^{13}$ SARC modified the second chapter of Circular Externa 100 of 1999, which is focused on credit risk management. Circular Externa 11 of 2002 was complemented by the "Carta Circular 31" of March 5, 2002", which established the timing for the implementation of SARC.

${ }^{14}$ The three phases were the following (Carta Circular 31 del 2002): (i) First, banks were required to prepare and present an implementation plan, (ii) second, banks were required to gather historical data and build information systems and software for the assessment and management of credit risk (iii) finally, banks were required to apply the methodology to estimated expected losses.
} 
A central point of the new risk management system was a provisioning scheme based on the expected losses of each individual loan. ${ }^{15}$ According to the new framework, expected losses were computed as follows,

$$
\text { Expected Loss }=P D^{*} E A D^{*} L G D
$$

where $P D$ is the probability of default (probabilidad de incumplimiento), EAD is the exposure at default (exposición del activo) (that is, the outstanding debt at the time of default), and $L G D$ is the expected loss given default (pérdida esperada de valor del activo dado el incumplimiento). This approach contrasts with the previous practice of defining provisions based on incurred losses, which was the provisioning scheme dictated by the major accounting standards at that time (i.e., IFRS39 and U.S. GAAP).

The new methodological framework to estimate expected losses of commercial loans was introduced in 2005 - in a later phase of the implementation of SARC - and is commonly known as Modelo de Referencia de Cartera Commercial (MRC). ${ }^{16}$ The MRC provides specific guidance for the estimation of $P D, E A D$, and $L G D$ (i.e., the parameters to compute expected losses). The effect of the new approach crucially depends on borrower size, the value of collateral, and the number of days in arrears. This is because MRC provides specific values of PD and LGD for a classification of borrowers based on size and credit rating (which, for existing clients, is a function of delinquency). Moreover, LGD is a function of loan collateral, and the value of collateral is adjusted based on the number of days in arrears. ${ }^{17}$ The MRC entered into effect on July $1^{\text {st }} 2007 .{ }^{18}$ As shown in Figure A1, when the new model was first implemented in the third quarter of 2007, macroeconomic conditions in Colombia were stable (the spillover of the 2008 financial crisis is not noticeable in the economic indicators until 2009). ${ }^{19}$

\footnotetext{
${ }^{15}$ The content of SARC is not restricted to the quantification of credit risk. SARC also introduced qualitative modifications in the second chapter of Circular Externa 100 of 1999 regarding policies, processes (including responsibility definitions), and specific rules.

16 The framework is defined in Circular 052 of 2004 (a major modification of chapter 2 of Circular Externa 100 of 1999) and in Circular 020 of 2005 (new Appendix III of chapter 2 of Circular Externa 100 of 1999).

${ }^{17}$ The regulatory document includes matrices containing estimates of the 12-month probability of default as a function of firm size (following the Law 905 of 2004, SARC classifies commercial firms as "Small", "Medium", and "Large"depending on the value of their assets) and the credit rating assigned to the borrower. The number of days in arrears is taken into account not only in the computation of PD, but also in that of LGD. The regulatory document also provides specific LGD values as a function of loan collateralization.

${ }^{18}$ The SFC developed MRC for commercial credit (which is the focus of our paper). For consumer credit, the SFC developed MRCO (i.e., "Modelo de Referencia de Cartera de Consumo"), which was published in December 2006 and entered into effect on July $1^{\text {st }}, 2008$.

${ }^{19}$ The Central Bank began to ease credit conditions at the end of 2008.
} 
The provisioning scheme based on expected losses introduced by SARC (and specifically, by the MRC) is remarkably similar to the Expected Credit Loss (ECL) model in recent accounting standards IFRS9 and ASU 2016-13 in the United States (also known as "CECL" or "Current Expected Credit Loss" model). To begin with, both rules switch the estimation of provisions from a model based on incurred losses to a model based on expected losses. As such, under SARC and IFRS9/CECL, the probability of default is positive at origination. Moreover, the parameters to compute expected losses are the same under SARC and IFRS9/CECL, namely PD, EAD, and $L G D$. Finally, both SARC and IFRS9/CECL require banks to measure these parameters as a combination of banks' estimations based on proprietary historical data and other specific quantities provided by the regulator. These similar features suggest that studying the effect of the expected loss model of SARC can shed light on the potential economic consequences of IFRS9/CECL. ${ }^{20}$ In a way, by introducing SARC, the SFC was pioneer in the implementation of loan provisioning based on expected losses, and thus a precursor of IFRS9 and CECL. This is especially important considering that there is still limited historical data to assess the effect of these important accounting standards.

\subsection{Prior Literature}

\subsubsection{Literature on Loan Loss Provisions}

A large literature in accounting studies loan loss provisions (LLP). One stream of this literature analyzes the information content of these provisions. To understand the credibility of LLP information, this research studies banks' motives to exercise discretion in LLP reporting, notably earnings management, regulatory capital management, and tax management (e.g., Beatty and Liao, 2014). As explained by Ryan (2011) and Beatty and Liao (2014), Beaver et al. (1989) started this literature by documenting a positive association between market value and loan loss provisions. Beaver et al. (1989) interpreted this finding as suggesting that, by reporting higher LLP, managers convey to the market that the bank can absorb the negative impact of LLP on earnings. Similarly, subsequent papers argue that a higher LLP signals a bank's ability to collect

\footnotetext{
${ }^{20}$ In contrast to IFRS9/CECL, the methodological framework introduced by SARC includes a countercyclical adjustment. However, while the adjustment methodology was published in 2007, the dynamic component of SARC provisions did not fully enter into force until 2010 (i.e., after the end of our sample period) and thus does not affect our inferences. For details on the Colombian banking regulation during our sample period, see also Gómez et al. (2019).
} 
bad debt (Elliot, Hanna, and Shaw, 1991; Griffin and Wallach, 1991). ${ }^{21}$ Ahmed, Takeda, and Thomas (1999) called into question these interpretations by finding that LLP is negatively related to stock returns (see also Collins, Shackelford, and Wahlen, 1995). In contrast to previous papers, these authors argue that, rather than by financial reporting incentives, discretion on LLP is driven by the need to meet regulatory capital requirements. ${ }^{22}$ More recently, other authors have examined additional dimensions of LLP reporting, including tax incentives (Andries, Gallemore, and Jacob, 2017), sentiment in the estimation of LLP (Hribar et al., 2017), the interaction between external auditors and bank regulators (Nicoletti, 2018), and bank competition (Tommy, 2019).

Another stream of research analyzes the relation between LLP and cyclicality. Laeven and Majnoni (2003)'s evidence suggests that a substantial number of banks around the world delay provisioning for credit losses, exacerbating the impact of the economic cycle on banks' profit and capital. Relatedly, Beatty, and Liao (2011), and Bushman and Williams (2012, 2015) find that banks that record timely LLP make good risk management decisions that reduce procyclicality. ${ }^{23}$

Finally, some papers study the effect of the dynamic component of the provisioning schemes introduced as part of the macro-prudential toolkit of some countries (Agénor, and da Silva, 2016; Jiménez et al., 2017; Gómez et al., 2020). Notably, Jiménez et al., (2017) show that dynamic provisioning smooths credit supply cycles and, in bad times, supports firm performance.

We add to prior literature on LLP in several ways. By examining the effect of a major rule change in LLP reporting (i.e., the introduction of the ECL model to estimate LLP), our study contributes to the empirical identification of the causal effect of loan loss provisioning on managerial decision making. But perhaps more importantly, we provide evidence that the

\footnotetext{
${ }^{21}$ Other papers in this literature include Wahlen (1994)'s, which points out the importance of controlling for NPLs and charge-offs, Liu and Ryan (1995)'s, which highlights the importance of loan type, and Beaver and Engel (1996)'s, which shows the importance of distinguishing between discretionary versus non-discretionary LLP. Liu, Ryan, and Wahlen (1997) find that positive association between loan loss provision and bank stock returns is only obtained by banks with low regulatory capital in the fourth fiscal quarter.

${ }_{22}$ Ryan (2011) and Beatty and Liao (2014) rationalize the mixed results of this literature by arguing that the determinants of LLP reporting and its capital-market effects depend on a number of factors: NPLs and charge-offs (Wahlen, 1994), loan types (Liu and Ryan, 1995), and the distinction between the discretionary and the nondiscretionary part of LLP (Beaver and Engel, 1996; Liu, Ryan, and Wahlen, 1997).

${ }^{23}$ Beatty and Liao (2011) find that banks that postpone recognition of loan losses are more likely to reduce lending under adverse credit conditions, which leads to higher lending pro-cyclicality. Bushman and Williams (2012) find that forward-looking provisions designed to smooth earnings dampen discipline over risk taking. In contrast, these authors also find that forward-looking provisions designed to reflect timely recognition of future losses are associated with enhanced discipline. Relatedly, Bushman and Williams (2015) show that delayed expected loan loss recognition is more common among more vulnerable banks.
} 
reporting of LLP affects banks' lending behavior and that the induced credit contraction affects the real economy (i.e., it affects borrowers' fundamentals). In contrast to the evidence on the effect of dynamic provisioning, our results suggest that ECL provisioning can exert a negative effect on credit and firm performance.

\subsubsection{Literature on the Expected Credit Loss Model}

The recent introduction of IFRS9 around the world and ASU 2016-13 in the United States (also known as CECL) has triggered a nascent literature on the ECL model. ${ }^{24}$ Part of this research develops models for estimating expected credit losses using publicly available information (e.g., Harris, Kahn, and Nissim, 2018; Lu and Nikolaev, 2019). Other research focuses on the informational consequences of the ECL model. In particular, the evidence in Beatty and Liao (2020) is consistent with the notion that the previous incurred credit loss (ICL) model imposed constraints that prevented banks from fully incorporating information about future losses (they show that, compared to reported provisions under the ICL model, analyst provision forecasts have incremental predictive power for future non-performing loans). Using a sample of international banks, López-Espinosa, Ormazabal, and Sakasai (2020) document that LLP amounts reported under the ECL model are more informative about bank risk than those reported under the ICL model. A few recent papers provide evidence consistent with the ECL model inducing an increase in provisions and a decrease in credit (Gaffney and McCann, 2019; Ertan, 2019; Löw, Schmidt, and Thiel, 2019).

Other recent research in banking studies the effect of the ECL model on procyclicality from a theoretical perspective, with the support of simulation techniques. Abad and Suarez (2018) show that the ECL model increases more suddenly the level of provisions than the ICL model when the economy switches from expansion to contraction. In turn, regulatory capital declines more severely at the beginning of the downturn. Buesa, Población, and Tarancón (2019) find that IFRS9 is less procyclical than IAS 39, but more procyclical than ASU 2016-13.

Our study contributes to the nascent literature on the ECL model by exploiting a regulatory change that occurred several years before the introduction of the IFRS9 and CECL. Studying the effect of the ECL model in different points in time is important to ensure that the inferences are

\footnotetext{
${ }^{24}$ ASU 2016-13 is short for "Accounting Standards Update (ASU) 2016-13, Financial Instruments — Credit Losses (Topic 326)". CECL stands for "Current Expected Credit Loss".
} 
not affected by the specific circumstances surrounding a given regulatory change. Moreover, we exploit a unique dataset whose granularity allows us to control for the confounding effects of credit supply and demand. But perhaps more crucially, ours is the first study to show that the ECL model has important real effects in both lender and borrower behavior, and that these effects vary crosssectionally based on borrower size and lender insolvency risk. We show that ECL provisioning induces a contraction of credit while having a mixed effect on banks' risk-taking behavior, evidence that provides insights into the regulatory tradeoff between economic growth and financial stability.

\section{Data}

In this section, we describe the data we use to identify the impact of the change in loan provisioning on local credit supply, bank risk-taking, and real effects. We merge three proprietary datasets. The first dataset contains supervisory quarterly information on commercial bank lending at the loan level. The second dataset contains annual financial information at the firm level from non-financial firms. The third dataset contains monthly financial information at the bank level.

The first dataset, at the loan-level, uses supervisory information on the universe of commercial loans. The data is obtained from reports sent quarterly by every commercial bank to SFC (the Colombian banking supervisor). Reports are mandatory, updated electronically, and include detailed characteristics of all the new and continuing loans made to firms by every bank in Colombia. All loans must be reported regardless of their size. For each loan, the dataset includes the issuing bank, the borrower, the outstanding amount, the (annualized) interest rate, the maturity of the loan, the fraction covered by collateral, and some information about the borrowing firm (size, location, and sector). We aggregate the observations at the firm-bank-quarter level, to which we refer to as "loan" level. Average loan characteristics are weighted by loan volume. Aggregated loan volume is the sum of the value of all outstanding loans that a firm holds from a certain bank in a given quarter (see definition in Table $\mathbf{A 1}$ in the appendix). Since loans are tracked quarterly, we can observe their evolution until maturity. Therefore, we observe whether the debtor obligations are being fulfilled, and if they are not, by how much and for how long each loan has been underperforming. Importantly, lenders are mandated to classify their borrowers into three categories_-small, medium, large_-based on the volume of the borrowers' reported assets. 
Finally, we exclude from our study loans to individuals pursuing entrepreneurial activity, as our study focuses on the real effects of loan loss provisioning on corporations.

The second dataset includes financial and balance sheet information at the firm level. The data is extracted from the Financial Statement Database processed by the Superintendencia de Sociedades (SS). ${ }^{25}$ The database includes a unique identification number, company name, place of incorporation, industry affiliation (sector), balance sheet information (i.e., assets, liabilities, and equity), and income statement information. We remove observations with negative assets, liabilities, and operational income. In addition, we exclude firms undergoing liquidation at the start of the sample period (such firms are under financial distress and behave differently from the rest). ${ }^{26}$

The third dataset contains financial information reported by all commercial banks to SFC. The data includes detailed monthly balance sheets and income statement information on the reporting banks. We use these data to construct bank-quarter level measures of bank size, risk, insolvency risk, capital, and performance.

We compare the relative impact of SARC on firms around the lower regulatory size threshold used to classify borrowers, namely COP 2.1 billion. In particular, we focus on firms with assets (measured in 2005) between COP 1.5 billion and COP 4.5 billion (i.e., roughly USD 500,000 and USD 1.5 million, respectively). As such, our sample includes firms classified as "small" (pequeñas) and firms classified as "medium" (medianas) by the Law 905 of 2004 (henceforth we refer to these groups as Smaller and Larger, respectively). In terms of empirical identification, our sample offers the advantage of including firms with similar characteristics but classified into two groups based on an arbitrary criterion (these are the firms closest to the regulatory size threshold). Finally, our sample period is defined as a symmetric window of one year (four quarters) around the introduction of SARC, namely from the second quarter of 2006 to the second quarter of 2008. Our sample consists of 41,354 firm-bank-quarter observations, 15 banks and 2,560 firms.

Table 1 presents descriptive statistics of the characteristics for the whole sample at the bank-firm-quarter, firm-year, and bank-quarter levels. The mean (median) loan value is COP 57

\footnotetext{
${ }^{25}$ The Superintendencia de Sociedades (Superintendence of Corporations) is a regulatory agency of the Government of Colombia that oversees corporations (see https://www.supersociedades.gov.co/SitePages/Inicio.aspx).

${ }^{26}$ As established by Law 550 from 1999, firms in liquidation are temporarily protected from creditors to give them time to restructure their operations, akin to Chapter 11 in the United States.
} 
million (COP 31 million), which corresponds to roughly USD 19,000 (10,000). ${ }^{27}$ The average provision rate is around 3.4 percent of loan value, while the average interest rate is 20 percent. Table 1 also shows that the average maturity is two years, that 20 percent of the loans are collateralized, and that 24 percent of loans are in arrears (i.e., the payments are at least one day late).

Table 2 presents a descriptive comparison of the two previously defined sample groups, namely Smaller and Larger firms. The quarterly variables are measured in 2007Q2, that is, in the quarter prior to the implementation of the reform (consistently, the annual variables are measured in 2006, that is, in the year prior to the implementation of the reform). As shown in the last two columns of Table 2, the statistical distribution of all variables is similar in the two groups, with all normalized differences statistically insignificant (Imbens and Wooldridge, 2009). The average loan loss provisions for Smaller and Larger firms are, respectively, 1.3 and 1.4 percent of the outstanding loan volume. The corresponding average interest rates are, respectively, 18.3 and 18.7 percent, the average maturity of loans is, respectively, 1.8 years and 2 years. The percentage of loans in arrears is also similar in the two groups (20.3 and 19.3, respectively). Smaller and Larger firms are also indistinguishable across several firm-level variables such as total value of loans, assets, liabilities, and sales. Finally, Table 2 also shows that the banks that serve both groups of firms also exhibit similar characteristics (solvency ratios, return on assets, and amount of nonperforming loans).

\section{The Effect of the Regulatory Change Across Borrowers}

\subsection{Loan Loss Provisions}

\subsubsection{Graphical Evidence}

As a first step to understand the impact of the new provisioning scheme, we analyze graphically the evolution of the volume of provisions around the introduction of SARC. We conduct this analysis to confirm that SARC indeed had a significant effect in bank provisioning (i.e., the regulation was effectively enforced). Figure 1 presents the average rate of provisions to outstanding loans for the quarters immediately before and after the implementation of SARC. To

\footnotetext{
27 Around 97 percent of the number of loans in our dataset are denominated in Colombian pesos. We restrict our analysis to loans in domestic currency. Including these loans does not alter our results in any significant way.
} 
further identify the effect of SARC, we split the sample into groups of borrowers that would be impacted differently by the new rules. In particular, we explore cross-sectional variation in the effect of SARC on the volume of provisions along the three main parameters used to compute the regulatory provision rate: borrower size, collateral, and delinquency (i.e., loans with significant numbers of days in arrears).

In Figure 1, Panel A, we split the sample into Smaller and Larger firms. Two important patterns emerge from this analysis. First, the average provisions increase significantly after the introduction of SARC. Second, the effect of the regulation is concentrated among Smaller firms. More concretely, the gap between the average provisions of the two groups widens significantly after the introduction of SARC (from around 1 percentage point to around 4 percentage points of outstanding loans).

In Figure 1, Panel B, we split the sample into loans with and without collateral. The figure shows that the increase in provisions is more pronounced among loans without collateral. Roughly, after SARC the difference between the provisions rate of loans without collateral increases from 0.1 percentage points to 1 percent point.

In Figure 1, Panel C, we split the sample into sectors with above/below median default rates (delinquencies greater than 90 days). Consistent with loan loss provisioning under SARC being more sensitive to the number of days in arrears, Panel $\mathrm{C}$ shows that, under the new regulation, firms in sectors with higher default rates exhibit a relatively higher increase in the level of provisions. Roughly, after the implementation of the new scheme the provisions rate in riskier sectors increases from 0.5 percentage points to 1 percentage point, relative to that in less risky sectors.

Overall, Figure 1 shows that, after the introduction of SARC, the overall level of loan loss provisions increases dramatically. The increase in provision rates is especially sharp among smaller borrowers, borrowers without collateral, and borrowers in sectors with high delinquency rates. This evidence is consistent with the predicted effect of SARC on loan loss provisions based on the key parameters defined in the regulation (i.e., borrower size, collateral, and delinquency) and thus confirms that SARC had a significant effect in bank provisioning (i.e., the regulation was effectively enforced). 


\subsubsection{Regression Analysis}

To analyze more formally the effect of SARC on the level of provisioning, we estimate the following model focusing on the two quarters around the implementation of the regulation (2007Q2 and 2007Q3):

$$
\begin{gathered}
\text { Provision }_{f, b, q}=\alpha+\beta_{1} \text { Post }_{q}+\beta_{2} \text { SmallFirm }_{f}+\beta_{3} \text { SmallFirm }_{f} * \text { Post }_{q}+\beta_{4} \text { Collateral }_{f, b, q}+ \\
\beta_{5} \text { Collateral }_{f, b, q} \text { Post }_{q}+\beta_{6} \text { Late }_{f, b, q}+\beta_{7} \text { Late }_{f, b, q} * \text { Post }_{q}+\varepsilon_{f, b, q}
\end{gathered}
$$

where Provision $_{f, b, q}$ is the ratio of provisions to loan value given to firm $f$ by bank $b$ in quarter $q$. Post $_{q}$ is an indicator variable that equals one in the third quarter of 2007 (i.e., the first quarter of implementation of SARC), and zero in the second quarter of 2007 (i.e., the quarter prior to the implementation of SARC). SmallFirm $f$ is an indicator of whether firm $f$ is in the Smaller group. Collateral $_{f, b, q}$ is the fraction of firm $f^{\prime}$ 's outstanding loans from bank $b$ in quarter $q$ that are covered by the firm's assets (the fraction is weighted by loan value). Late $f, b, q_{\text {is }}$ an indicator of whether firm $f$ holds a loan in arrears from bank $b$ in quarter $q$.

Table 3 presents the results of this analysis. In columns (1) and (2) we conduct the analysis separately for the quarter before the implementation of SARC - 2007Q2 - and the first quarter of the implementation of SARC-2007Q3. Column (1) shows that, prior to the implementation of the new provisioning scheme, bank provisions were unrelated to borrower size and to loan collateral. Somewhat surprisingly, column (1) also shows that the provision rate is not significantly higher for loans in arrears. In contrast, column (2) shows that, under SARC, provisions are higher for smaller firms, for loans without collateral, and for loans in arrears. Column (3) presents the results of estimating equation (1) pooling observations from 2007Q2 and 2007Q3. Column (3) confirms that, under SARC, the average provision rate of loans is higher than in the quarter prior to the reform (the baseline increase is 2.4 percent). Column (3) also confirms that the increase in provisions after the reform is concentrated among smaller firms and uncollateralized loans (the increase in provisions is also more pronounced among loans in arrears, but the difference is not statistically significant).

One potential concern about the results in columns (1)-(3) is that the documented increase in provisions could be confounded by a simultaneous increase in loan defaults (such an increase in loan defaults could be a random coincidence or could reflect the possibility that the regulation 
was introduced in anticipation of a deterioration in the credit conditions). In columns (4) and (5) we assess the empirical validity of this concern. In particular, we replace the dependent variable with Default $_{f, b, q}$, an indicator variable that equals one if firm $f$ holds a loan from bank $b$ in quarter $q$ that is more than 90 days past due. In contrast to the results in column (3), the coefficient on SmallFirm $_{f}^{*}$ Post $_{q}$ and the coefficient on Collateral $f b q{ }^{*}$ Post $_{q}$ are not statistically significant. That is, we find no significant increase in the default rates in the quarter of the implementation of the reform. ${ }^{28}$ In summary, the results in Table 3 confirm that the implementation of SARC induced an increase in the level of provisions, particularly for small firms, uncollateralized loans, and (to a lesser extent) loans in arrears.

\subsection{Credit Supply}

In this section, we study whether the increase in provisions induced by SARC affects credit supply. To measure changes in credit supply, we focus on three main loan characteristics capturing lending volume and lending conditions: loan value, interest rate, and loan maturity. In consistency with prior tests, we explore cross-sectional variation on the effect of SARC on credit supply along the three main parameters used to compute the regulatory provision rate (i.e., borrower size, collateral, and delinquency). Exploiting this cross-sectional variation sharpens identification, as the effect of SARC is expected to vary with these three parameters.

\subsubsection{Borrower Size}

We first analyze the impact of SARC on these loan characteristics on a quarter by quarter basis. Specifically, we test:

$$
y_{f, b, q}=\alpha+\sum \beta_{q} \text { SmallFirm }_{f}^{*} \text { Quarter }_{q}+\gamma_{f, b}+\gamma_{b, q}+\varepsilon_{f, b, q}
$$

where $y_{f, b, q}$ are a series of loan-level variables - provisions, volume, maturity, and interest rateaggregated at the firm-bank-quarter level (i.e., firm $f$, bank $b$, and quarter $q$ ). SmallFirm $f$ is an indicator variable for whether the firm is the Smaller group. Quarter $q$ is an indicator for quarter $q$. Equation (2) also includes firm-bank fixed effects $\gamma_{f, b}$, to control for time-invariant firm-bank characteristics (including the determinants of firm-bank matching), as well as bank-quarter fixed

\footnotetext{
${ }^{28}$ Moreover, the credit quality remains stable during 2007-2008 as shown in Reporte de Estabilidad Financiera, 2009.
} 
effects $\gamma_{b, q}$ to control for quarterly movements in credit supply at the bank level. We exclude the quarter prior to the implementation of SARC-2007Q2 - so that all coefficients of interest are relative to that quarter. Standard errors are double-clustered at the firm-bank and quarter levels.

Figure 2 presents the results of estimating equation (2) for loan value, interest rate, and maturity. For completeness, we also re-estimate equation (2) using provision rates as alternative dependent variables. In consistency with prior analyses, Panel A shows that, under SARC, the increase in provision rates is significantly stronger for smaller firms. By the end of our sample period, the average provision rate of smaller firms is 4 percent larger than that of larger firms (relative to the quarter of the implementation of the reform). This relative increase in the provision rate of loans to smaller firms increases the opportunity cost associated with lending to this group of firms. This suggests that the implementation of the new provision scheme could have led to a relative tightening of credit terms for smaller firms.

The evidence in Panels B, C, and D is consistent with this idea. Panel B shows that, under SARC, the volume of lending to smaller firms gradually declines relative to that of large firms. By the end of the sample period, the value of loans to smaller firms is 10 percent lower than that to larger firms. Consistent with a tightening of lending conditions to smaller firms, Panel C shows a relative increase in the interest rate paid by smaller firms on their loans. By the end of the sample period the difference in the interest rate charged to smaller firms relative to that of larger firms increases 0.6 percent relative to the quarter of the implementation of the reform. In parallel, Panel D shows a relative decline in the maturity of loans to smaller firms (around 6 percent), relative to the quarter of the implementation of the reform.

In consistency with our prior analyses, we estimate the following model as an alternative way of gauging whether SARC affected credit supply across smaller and larger firms:

$$
y_{f, b, q}=\alpha+\beta \text { SmallFirm }_{f} * \text { Post }_{q}+\gamma_{f, b}+\gamma_{b, q}+\gamma_{s, q}+\varepsilon_{f, b, q}
$$

where $y_{f, b, q}$ and SmallFirm $f$ are defined as in equation (2), and Post $t_{q}$ is an indicator variable for quarters after 2007Q2. In addition to the firm-bank fixed effects $\gamma_{f, b}$, and bank-quarter fixed effects $\gamma_{b, q}$, we also include sector-quarter fixed effects, $\gamma_{s, q}$ to control for variations in credit demand at the sectorial level. Standard errors are double-clustered at the firm-bank and quarter level. The results of estimating equation (3) show that, under SARC, banks reduce the supply of credit to 
smaller firms (Table 4, columns 1-3). The estimated coefficients point to a relative reduction of around 16 percent (columns 1-3). Consistently, the results in columns (4)-(6) show a relative increase in the interest rate charged to smaller firms of roughly 0.5 percent. In parallel, columns (7)-(9) reveal that, after the reform, the average loan maturity of smaller firms declined by roughly 6 percent relative to that of larger firms.

\subsubsection{Collateralizability}

Next, we exploit cross-sectional variation in the second of the main parameters determining the provision rate under SARC, namely collateralization. To capture this variation ex-ante (i.e., before the loan contract) we use asset tangibility, as tangible assets are easier to use as collateral than intangible assets (e.g., Jímenez and Saurina, 2004; Mayordomo, 2019). Thus, we test whether the post-SARC reduction in the supply of credit to smaller firms is even more pronounced in sectors where firms have relatively fewer tangible assets. ${ }^{29}$ In particular, we estimate the following model:

$$
\begin{gathered}
y_{f, b, q}=\alpha+\beta_{1} \text { TangibleSector }_{s}{ }^{* \text { Post }_{q}}+\beta_{2} \text { SmallFirm }_{f} * \text { Post }_{q}+\beta_{3} \text { TangibleSector }_{s} \\
{ }^{*} \text { SmallFirm }_{f} * \text { Post }_{q}+\gamma_{f, b}+\gamma_{b, q}+\gamma_{s, q}+\varepsilon_{f, b, q}
\end{gathered}
$$

where $y_{f, b, q}$, SmallFirm $_{f}$, and Post $_{q}$ are as previously defined (see equation (3)). TangibleSector is an indicator variable that equals one if the average ratio of fixed assets over total assets in sector $s$ (i.e., the sector in which firm $f$ operates) is below the sample median, and zero otherwise. The fixed effect structure of equation (4) is as in equation (3). We include firm-bank fixed effects, $\gamma_{f, q}$, bank-quarter fixed effects, $\gamma_{b, q}$, and sector-quarter fixed effects, $\gamma_{s, q}$.

Table 5 presents the results. As shown in columns (1)-(2), the post-SARC relative decrease in credit supply for smaller firms is particularly pronounced in less tangible sectors, that is, among firms whose assets are more difficult to collateralize. The magnitude of the coefficient $\beta_{3}$ suggests that the difference in this relative decrease in credit supply is economically meaningful (around 13 percent). Consistently, columns (3)-(4) show that the post-SARC relative increase in interest rates for smaller firms is particularly pronounced in less tangible sectors. The magnitude of the coefficient $\beta_{3}$ suggests a difference in this relative increase of around 0.4 percent. Overall,

\footnotetext{
${ }^{29}$ We define tangibility as the ratio of fixed assets to total assets. We exclude mobile assets, given that the registry of mobile guarantees was only implemented in 2013 with Law 1676. For exposition purposes, in Table A2, we display the top- and bottom-10 3-digit sectors (ISIC Rev 3) by tangibility of assets.
} 
the results in Table 5 suggest that the post-SARC tightening of credit margins to smaller firms is more pronounced among firms with assets that are more difficult to use as collateral in loan contracts.

\subsubsection{Delinquency}

Finally, we exploit cross-sectional variation in the third of the main parameters determining the provision rate under SARC, namely loan delinquency (i.e., loans in arrears). In parallel to the previous analyses, we test whether the post-SARC reduction in the supply of credit to smaller firms is even more pronounced among firms with loans in arrears. In particular, we estimate the following model separately for the subsamples of smaller and larger firms:

$$
y_{f, b, q}=\alpha+\beta_{1} \text { Default }_{\mathrm{f}, b, q}+\beta_{2} \text { Default }_{\mathrm{f}, b, q} * \text { Post }_{q}+\gamma_{f, b}+\gamma_{b, q}+\varepsilon_{f, b, q}
$$

where $y_{f, b, q}$, SmallFirm $_{f}$, and Post $_{q}$ are as previously defined (equation (3)). Default $t_{\mathrm{f}, b, q}$ is an indicator variable that equals one if firm $f$ holds a loan from bank $b$ in quarter $q$ that is more than 90 days in arrears, and zero otherwise. In parallel to prior tests, we include firm-bank fixed effects $\gamma_{f, b}$ and bank-quarter fixed effects $\gamma_{b, q}$.

The results of this test (Table 6) confirm that the post-SARC relative tightening of credit supply for smaller firms is particularly pronounced among borrowers with loans in arrears. In particular, after the reform, Table 6 reveals a 60 percent relative decrease in loan volume to smaller borrowers with loans in arrears. Consistently, the results point at a corresponding 27 percent reduction in loan maturity for this subgroup. Overall, the results in Table 6 suggest that the postSARC tightening of credit margins to smaller firms is more pronounced among firms with delinquent loans.

\subsection{Real Effects}

In this section we analyze whether the post-SARC credit contraction among smaller firms translates into an impact on the real activity of these borrowers. Whether the real effects of such credit contraction are first order is an empirical question, as in theory borrowers can resort to alternative financing sources. We conduct this analysis at the firm-level using annual balance sheet data from 2005 to $2007 .{ }^{30}$ We use annual data because Colombian commercial firms are

\footnotetext{
${ }^{30}$ Our sample period includes the years 2006 and 2007 because SARC was first implemented in 2007. We also include the year 2005 to check for pre-trends in our data. We exclude 2008 to avoid observations after the Lehman Brothers
} 
required to disclose financial reports only once a year (i.e., we do not have quarterly financial information for our sample of Colombian commercial firms). In particular, we estimate the following model:

$$
z_{f, y}=\alpha+\beta_{1} \text { SmallFirm }_{f} * \text { Pre }_{y}+\beta_{2} \text { SmallFirm }_{f} * \text { Post }_{y}+\gamma_{f}+\gamma_{b, y}+\gamma_{r, s, y}+\varepsilon_{f, y}
$$

where the dependent variable $z_{f, y}$ is one of the following four variables for firm $f$ in year $y$. Valuefy is the logarithm of the total value (in pesos) of firm f's outstanding loans in year $y$. Liabilities $f y$ is the logarithm of firm f's total liabilities (in pesos) in year $y$. Assets $f y$ is the logarithm of firm $f^{\prime}$ s total assets (in pesos) in year $y$. Sales $f, y$ is the logarithm of firm f's total revenues (in pesos) in year

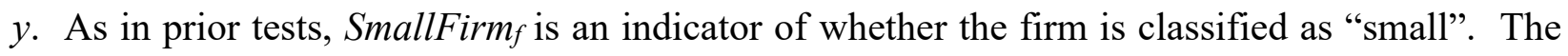
regressor Pre $_{y}$ is an indicator variable that equals one if the observation corresponds to year 2005, and zero otherwise. We include this variable to check for pre-trends. Post y $_{\text {is }}$ an indicator variable that equals one if the observation corresponds to year 2007 (i.e., the first year of the implementation of SARC), and zero otherwise. Finally, we also include firm fixed effects $\gamma_{f}$, bankyear fixed effects $\gamma_{b, y}$, and region-sector-year fixed effects $\gamma_{r, s, y}$ to control for demand shocks. ${ }^{31}$

Table 7 presents the results. Column (1) reveals that, while there are no pre-trends in loan volume, the value of loans granted to smaller firms exhibits a relative decline of 30 percent in the year of the implementation of the reform. Consistently, column (2) shows a relative decline in total firm liabilities (many of which are bank loans) of 30 percent. This suggests that our sample firms were not able to substitute bank lending for other debt contracts. The evidence in Table 7 is consistent with the notion that the contraction of credit had significant consequences in firm investment and in firm performance. Column (3) shows a 20 percent relative decline in the assets of smaller borrowers after the implementation of the new provisioning scheme. In parallel, column (4) uncovers a relative 12 percent decrease in the sales of smaller firms.

\section{The Effect of the Regulatory Change Across Lenders}

In this section we examine more closely whether SARC affected banks' risk-taking behavior. First, we test whether, under SARC, banks avoid riskier sectors. Second, we explore

crisis. As a robustness check, we repeat the analysis including data from 2008 . The results are very similar to the ones using the sample ending in 2007.

${ }^{31}$ In cases where the firm holds loans from more than one bank, the bank-year fixed effects are defined based on the bank from which the firm holds the largest value of outstanding loans. 
whether, at the same time (and to the extent possible), banks engage in "search for yield". Third, we analyze whether SARC affects the characteristics of the sample banks' portfolio of loans (i.e., the composition and concentration of such portfolios). To sharpen identification, we conduct these analyses exploiting cross-sectional variation in the insolvency risk of our sample banks. We focus on cross-sectional variation in banks' insolvency risk because the effect of the reform is likely to be more pronounced among banks with less ex-ante capital (these banks have less capacity to take on higher provisions because they are closer to the minimum capital requirements, and provisions affect the income statement and thus shareholder equity). Henceforth we refer to banks with a higher (lower) insolvency risk as "weaker" ("stronger”) banks.

\subsection{Avoidance of Risky Sectors}

We first analyze whether weaker banks tighten relatively more their credit terms to borrowers operating in riskier sectors (i.e., whether they avoid risky sectors that would induce an increase in provisions). For this analysis, we test the following variant of equation (3):

$$
y_{f, b, q}=\alpha+\beta \text { SmallFirm }_{f} * \text { Post }_{q}+\beta \text { SmallFirm }_{f} * \text { Post }_{q} * \text { InsolvencyRisk }_{b, 07 Q 2}+\gamma_{f, b}+\gamma_{b, q}+\gamma_{s, q}+\varepsilon_{f, b, q}
$$

where $y_{f, b, q}$ SmallFirm $_{f}$ and Post $_{q}$ are defined as in equation (3). InsolvencyRisk, $k_{b 7 Q 2}$ is defined as $(-1)^{*}$ Solvency $y_{b, 072}$, where Solvency $y_{b, 072}$ the solvency ratio of bank $b$ in 2007Q2 (i.e., the quarter prior to the implementation of the reform), computed as the ratio of tier1 capital to risk-weightedassets. As in equation (3), we include firm-bank fixed effects $\gamma_{f, b}$, bank-quarter fixed effects $\gamma_{b, q}$, and sector-quarter fixed effects, $\gamma_{s, q}$. Furthermore, in some specifications we replace sector-quarter fixed effects $\gamma_{s, q}$ with firm-quarter fixed effects, $\gamma_{f, q}$, to further control for credit demand. The inclusion of firm-quarter fixed effects restricts the sample to firms borrowing simultaneously from at least two different banks, which causes substantial sample attrition (Khwaja and Mian, 2008). To test whether weaker banks tighten relatively more their credit terms to borrowers operating in riskier sectors, we split our sample based on the percentage of defaults (i.e., loans with more than 90 days in arrears) in the firm's sector. We refer as Lower (Higher) Risk Sectors to sectors with below (above) median percentage of defaults.

Table 8, Panel A presents the results for the sample firms in lower-risk sectors. The results indicate that stronger and weaker banks show no statistically significant patterns in loan value and interest rates. However, smaller firms borrowing from weaker banks exhibit a decrease in the 
average maturity of their loans (a one standard deviation decrease in bank insolvency risk is associated with a 3.8 percent decrease in maturity). All in all, Table 8, Panel A shows that, under SARC, lending margins in lower-risk sectors do not vary much based on borrower size and bank insolvency risk.

Table 8, Panel B presents the results for the sample firms in higher-risk sectors. In contrast with Panel A (i.e., higher-risk sectors), we observe substantial post-SARC variation in lending margins based on borrower size and bank solvency. Columns (1)-(3) reveal a substantial postSARC decline in the loan volume for smaller firms (around 12 percent), a decrease that is concentrated among borrowers banking with weaker banks (a one standard deviation increase in insolvency risk is associated with a 7.8 percent reduction in lending). This result is robust to including firm-quarter fixed effects.

Consistently, columns (4)-(6) reveal a substantial post-SARC increase in loan interest rates for smaller firms (around 0.9 percent), and the increase is concentrated among borrowers banking with weaker banks (a one standard deviation decrease in insolvency risk is associated with a 0.3 percent increase in interest rates). The results on loan maturities in columns (7)-(9) are also consistent with a tightening of credit conditions for smaller borrowers banking with weaker banks. Overall, the results in Table 8 are consistent with the notion that SARC induced weaker banks to contract credit to smaller borrowers operating in riskier sectors in an attempt to avoid borrowers that require higher regulatory provisions.

\subsection{Search for Yield}

To further understand how SARC affects banks' risk-taking behavior, we next analyze whether the previously documented contraction in lending to smaller firms induced banks to search for yield within the constraints imposed by the regulation. In particular, we test whether weaker banks switch credit from firms with lower ex-ante loan interest rates to firms with higher ex-ante loan interest rates (which historically tend to have higher ex-post default rates). To do so, we partition the sample based on borrowers' ex-ante yield, calculated as the average interest rate (weighted by loan value) at the firm-bank-quarter level. We refer to the firm-bank-quarter observations with below (above) median values of the average loan interest rate (weighted by loan value) as (ex-ante) Lower (Higher) Yield Borrowers. We then re-estimate equation (7) separately for these two subsamples. 
Table 9, Panel A (Panel B) presents the results for lower-yield (higher-yield) borrowers. The contrasting results in columns (1) and (2) of these two panels are consistent with the notion that banks contract their lending to smaller borrowers with lower yield, but do not reduce credit to similar borrowers with higher yield. For the subsample of lower-yield borrowers (i.e., Panel A), we observe a relative reduction in the value of loans to smaller firms of around 6 percent. However, for the subsample of higher-yield borrowers (i.e., Panel B), that relation is statistically insignificant. These patterns vary with bank insolvency risk. Panel A shows that weaker banks reduce relatively more their lending to small firms with lower yield (e.g., a one standard deviation increase in insolvency risk is associated with a lending decrease of 10.8 percent). In contrast, Panel B shows the reversed pattern for the sample of higher-yield borrowers. Based on the results in column (2) of this second panel, a one standard deviation increase in insolvency risk is associated with a lending increase of 20 percent.

Regarding loan characteristics, Table 9 shows that smaller firms with higher yields exhibit smaller declines in loan maturity than similar firms with lower yields. The impact on interest rates is more nuanced. For the subsample of lower-yield borrowers, the interest rates of smaller firms experience a relative increase of 0.8 percent, but the pattern does not vary with bank insolvency risk. However, for the sample of higher-yield borrowers, the interest rates of smaller firms increase relatively more when the loans are extended by weaker banks. In summary, the results in Table 9 indicate that, under SARC, weaker banks reduce credit to smaller firms with lower yield—now costlier to serve - while increasing their exposure to smaller firms with higher yield, which are riskier but more profitable for the bank. As such, the evidence in Table 9 suggests that SARC induces weaker lenders to engage in "search-for-yield" within the constraints of the regulation as an attempt to make up for the lower profitability induced by the increase in provisions.

\subsection{Loan Portfolio Characteristics}

\subsubsection{Portfolio Composition}

We next analyze whether the change in bank lending behavior elicited by SARC is strong enough to result in a reshaping of the loan portfolio of weaker banks (i.e., the banks most affected by the reform). To do so, we collapse observations at the bank-quarter level and estimate the following model: 


$$
y_{b, q}=\alpha+\beta_{1} \text { Post }_{q}+\beta_{2} \text { Post }_{q} \text { InsolvencyRisk }_{b, 07 Q 2}+\gamma_{b}+\gamma_{q}+\varepsilon_{b, q}
$$

where $y_{b, q}$ is one of the following variables measured at the bank-quarter level. Loans $b, q$ is the total value of outstanding loans of bank $b$ in quarter $q$. TangibilitySector $b_{b, q}$ is the average tangibility (measured as ratio of fixed assets to total assets) of the sectors of the borrowers of bank $b$. RiskSector $_{b, q}$ is the weighted average rate of default (computed as the percentage of loans in arrears for more than 90 days) of the sectors of bank's borrowers. CreditHistory $y_{b, q}$ is the average years of relation between a bank and its borrowers. Finally, LoansDefault,$q$ is the ratio of non-performing loans to total bank assets of bank $b$ in quarter $q$. On the right-hand side, Post $t_{q}$ and InsolvencyRisk $b_{b, 07 Q 2}$ are as previously defined. Equation (8) also includes bank fixed effects $\gamma_{b}$ as well as quarter fixed effects $\gamma_{q}$.

Table 10 presents the results. Columns (1) and (2) show that, under SARC, weaker banks decrease their total lending relative to stronger banks (a one standard deviation increase in insolvency risk is associated with a 5 percent decrease in bank lending). Columns (3) and (4) show that, under SARC, weaker banks extend relatively more credit to borrowers operating in sectors with more tangible assets (that is, assets that are easier to use as collateral). Columns (5) and (6) show that, under SARC, weaker banks are more likely to shun riskier sectors (that is, sectors with higher fraction of late repayment). Columns (7) and (8) analyze the type of borrower that banks serve, as indicated by the length of the borrower-bank relationship (i.e., the "credit history"). The results indicate that weaker banks extend relatively more credit to borrowers with a relatively longer credit history. Taken together, the evidence in Table 10 is consistent with our prior results and suggests that weaker banks reduce credit and engage in lending behavior that minimizes the increase in provisions induced by SARC.

\subsubsection{Portfolio Concentration}

Finally, we check whether SARC affects the concentration of banks' portfolios across borrowers and sectors. In particular, we estimate the following model:

$$
\begin{gathered}
y_{b, q}=\alpha+\beta_{1} \text { Post }_{q}+\beta_{2} \text { Post }_{q}{ }^{*} \text { InsolvencyRisk }_{b, 07 Q 2}+\beta_{3} \text { Post }_{q} * \text { SmallFirm }_{b, 07 Q 2}+ \\
\beta_{4} \text { Post }_{q}{ }^{*} \text { InsolvencyRisk }_{b, 07 Q 2} * \text { SmallFirm }_{b, 07 Q 2}+\gamma_{b}+\gamma_{q}+\varepsilon_{b, q}
\end{gathered}
$$

where $y_{b, q}$ is one of the following two measures for bank $b$ in quarter $q$. Herfindahl Firms $s_{b, q}$ is the Herfindahl index of the borrowers in a bank's lending portfolio (i.e., the Herfindahl index at the 
firm level). The index is computed as the sum of the squares of the shares of the borrowers in the portfolio of loans (the share of a borrower in the portfolio is computed as the value of the loans to that borrower divided by the aggregated value of the loans in the portfolio). Herfindahl Sectors $s_{b, q}$ is the Herfindahl index of sectors of the borrowers in a bank's lending portfolio (i.e., the Herfindahl index at the sector level). As before, the index is the sum of the squares of the shares of the sectors in the loan portfolio (the share of a sector in the portfolio is computed as the value of the loans to borrowers in that sector divided by the aggregated value of the loans in the portfolio). Post $q$ and InsolvencyRisk $k_{b, 07 Q 2}$ are as previously defined and SmallFirm ${ }_{b, 07 Q 2}$ is the fraction of smaller firms in the bank b's loan portfolio in the quarter prior to the reform. Also, as in prior tests, equation (9) includes bank fixed effects $\gamma_{b}$, as well as quarter fixed effects $\gamma_{q}$.

Table 11 presents the results. Columns (1)-(3) analyze the concentration of borrowers in banks' loan portfolios, while Columns (4)-(6) analyze the concentration of sectors in banks' loan portfolios. The results suggest that, after the reform, the loan portfolios of weaker banks become more concentrated (the pattern holds regardless of whether the Herfindahl index is computed at the firm level or at the sector level). The magnitude of the effect is economically meaningful. A one standard deviation increase in insolvency risk is associated with an increase in the firm-level (sector-level) Herfindahl index of 10 percent (60 percent). Furthermore, columns (3) and (6) reveal that the increase in portfolio concentration is even larger for banks with a higher ex-ante exposure to smaller borrowers. All in all, the results in Table 11 suggest that, under SARC, the portfolio of loans of weaker banks becomes more concentrated. The evidence also suggests that this increase in portfolio concentration is likely a consequence of weak banks' reduction of their exposure to small borrowers.

Taken together, the evidence in Table 10 and Table 11 suggests that the effect of SARC on bank risk-taking is nuanced. While bank portfolios become more "conservative" (i.e., smaller loan volume, well-known clients, and sectors with lower risk and more tangible assets), those portfolios are more concentrated, and thus provide less risk diversification. Thus, similar to the results in Table 8 and Table 9 (i.e., banks avoid risky lenders while engaging in "search for yield" within the constraints of the regulation), the patterns in Table 10 and Table 11 suggest that the effect of SARC on bank risk-taking is mixed. 


\section{Conclusions}

We study the economic consequences of a rule change in Colombia that mandated the estimation of banks' loan loss provisions (LLP) based on expected credit losses (ECL), as opposed to LLP based on incurred credit losses (ICL). The new methodology was introduced in the context of the Sistema de Administración de Riesgo de Crédito (SARC), a major reform of the system used by banks to assess credit risk.

Consistent with the regulation having a strong effect on bank provisioning, we observe a remarkable increase in the overall level of provisions around the introduction of the regulation. Consistent with the cross-sectional aspects of the regulation, the increase is concentrated among smaller borrowers, loans without collateral, and loans granted to borrowers operating in riskier sectors. In parallel, we observe a significant tightening of credit margins for smaller borrowers (under the new regime, smaller firms obtain relatively less credit, pay higher interest rates, and are granted loans with shorter maturity). These patterns are concentrated in sectors with fewer tangible assets (i.e., assets more difficult to collateralize) and among smaller borrowers with defaulted loans (i.e., a subset with a high proportion of "zombie" firms).

The new provisioning scheme appears to have significant consequences on the real economy in terms of growth and decreasing unemployment. We find that the liabilities, assets, and sales of smaller borrowers (more affected by the regulation) decrease substantially after the implementation of SARC.

The effect of SARC on bank risk-taking is mixed. Banks with higher insolvency risk (and thus less capacity to take on higher provisions) avoid borrowers that induce higher provisions (typically riskier borrowers), but these banks also engage in "search for yield" within the constraints of the regulation to mitigate the negative effect of higher provisions on bank profitability. While bank portfolios become more "conservative" (i.e., smaller loan volume, wellknown clients, and sectors with lower risk and more tangible assets), those portfolios are more concentrated, and thus provide less risk diversification.

Our results have implications for the ongoing debate on the economic consequences of estimating loan loss provisions based on expected credit losses, a provisioning scheme embraced by recent accounting standards around the world (i.e., IFRS9 and CECL). Critically, while the 
ECL model was proposed in the aftermath of the global 2008 financial crisis as a response to the perception that, under the ICL model, bank provisioning was insufficient and untimely, currently there is the concern that, under some circumstances such as the recent COVID-19 crisis, the ECL exacerbates procyclicality. Our results (i.e., that SARC induced a credit contraction while having a mixed effect on bank risk-taking) support the validity of this concern. 


\section{References}

Abad, J. and Suarez, J. "The Procyclicality of Expected Credit Loss Provisions." CEPR Discussion Paper No. DP13135, 2018.

Acharya, V. and Ryan, S. (2016). "Banks' financial reporting and financial system stability." Journal of Accounting Research 54: 277-340.

Acharya, V. V., Hasan I., and Saunders, A. (2006). "Should banks be diversified? Evidence from individual bank loan portfolios." Journal of Business 32, 1355-1412.

Agarwal, S. and Hauswald, R. (2010). "Distance and private information in lending." Review of Financial Studies 23: 2757-88.

Agarwal, S. Chomsisengphet, S., Mahoney, N., and Stroebel, J. (2018). "Do banks pass through credit expansions to consumers who want to borrow?" Quarterly Journal of Economics 133 (1), 129-190.

Agénor, P. and da Silva, L. (2016), "Reserve requirements and loan loss provisions as countercyclical macroprudential instruments: A perspective from Latin-America." IDB Policy Brief (250).

Ahmed, A.S., Takeda, C., and Thomas S. (1999) "Bank loan loss provisions: A re-examination of capital management, earnings management and signaling effects." Journal of Accounting and Economics 28: 1-25.

Andries, K., Gallemore, J. and Jacob, M. (2017) "The effect of corporate taxation on bank transparency: Evidence from loan loss provisions." Journal of Accounting and Economics 63: $307-328$.

Beaver, W., Eger, C., Ryan, S. and Wolfson, M. (1989) "Financial reporting, supplemental disclosures, and bank share prices.” Journal of Accounting Research 27: 157-178.

Beaver, W. and Engel, E. (1996) "Discretionary behavior with respect to allowances for loan losses and the behavior of security prices." Journal of Accounting and Economics 22: 177-206.

Beck, T., Degryse, H., De Haas, R., and Van Horen, N. (2018). "When arm's length is too far. Relationship banking over the business cycle.” Journal of Financial Economics 127: 174-196.

Becker, Bo and Ivashina, V., (2015) "Reaching for yield in the bond market." Journal of Finance, Volume 70: 1863-1902.

Bischof, J., Laux, C. and Leuz, C. (2019) "Accounting for Financial Stability: Lessons from the Financial Crisis and Future Challenges.” ECGI Law Working Paper No. 445. 
Bolton, P., Freixas, X., Gambacorta, L. and Mistrulli, P.E. (2016). "Relationship and transaction lending in a crisis." Review of Financial Studies 29: 2643-2676.

Borio, C., and Restoy, F. (2020) "Reflections on regulatory responses to the Covid-19 pandemic." Financial Stability Institute (Bank for International Settlements), FSI Brief No 1.

Boyd, J. and De Nicoló, G. (2005). "The theory of bank risk taking and competition revisited." The Journal of Finance 60: 1329-1343.

Buesa, A., Población, F.J. and Tarancón, J. (2019) "Measuring the procyclicality of impairment accounting regimes: A comparison between IFRS9 and US GAAP." ECB Working Paper Series No. 2347.

Bushman R. and Williams, C. (2012) "Accounting discretion, loan loss provisioning, and discipline of banks' risk-taking." Journal of Accounting and Economics 54: 1-18.

Bushman R. and Williams, C. (2015) "Delayed expected loss recognition and the risk profile of banks." Journal of Accounting Research 53: 511-553.

Collins, J., Shackelford, D. and Wahlen, J. (1995) "Bank differences in the coordination of regulatory capital, earnings and taxes." Journal of Accounting Research 33: 263-291.

Degryse, H. and Van Cayseele, P. (2000) "Relationship lending within a bank-based system: Evidence from European small business data." Journal of Financial Intermediation 9: 90-109.

Di Maggio, M., Kermani, A., Keys, B.J., Piskorski, T, Ramcharan, R., Seru, A. and Yao, V. (2017). "Interest rate pass-through: Mortgage rates, household consumption, and voluntary deleveraging." American Economic Review 107: 3550-3588.

Elliot, J.A., Hanna, J.D., and Shaw, W.H. (1991) "The evaluation by the financial markets of changes in bank loan loss reserve levels." The Accounting Review 66: 847-861.

Ertan, A., (2019) “Expected Losses, Unexpected Costs?” SSRN Working Paper, No. 3504708.

FDIC (2020), "Request for Delay in Transitions to and Exclusions from Certain Accounting Rules".

Freixas, X. and Rochet, J. (2008) “Macroeconomics of banking.” MIT Press

Gaffney, E. and McCann, F. (2019). "The cyclicality in SICR: Mortgage modelling under IFRS9." European Systemic Risk Board (No. 92).

Gaston, E., and Song, I. (2014) "Supervisory roles in loan loss provisioning in countries implementing IFRS.” International Monetary Fund Working Paper 14/170. 
Gómez, E., Lizarazo, A., Mendoza, J., Murcia, A., (2020). "Evaluating the impact of macroprudential policies in Colombia." Journal of Financial Intermediation 42: 1008-43.

Gorton, G., and Ordoñez, G. (2014) “Collateral crises.” American Economic Review 104 (2): 343 378.

Griffin, P. and Wallach, S. (1991) "Latin American lending by major U.S. banks: The effects of disclosures about nonaccrual loans and loan loss provisions." The Accounting Review 66: 830846.

Hribar, P., Melessa, S.J., Small, R.C. and Wilde, J.H. (2017) "Does managerial sentiment affect accrual estimates? Evidence from the banking industry." Journal of Accounting and Economics 63: $26-50$.

Huizinga, H.P and L. Laeven. (2019). "The procyclicality of banking: Evidence from the Euro Area”. IMF Economic Review 67 (3), 496-527.

IFRS, (2020). "IFRS9 and COVID-19”. https://cdn.ifrs.org/-/media/feature/supportingimplementation/ifrs-9/ifrs-9-ecl-and-coronavirus.pdf?la=en

IMF. (2008). Colombia: Staff Report for the 2007 Article IV Consultation, IMF Country Report No. 08/3, International Monetary Fund, Washington DC.

Imbens, G., and Wooldridge, J. (2009). "Recent developments in the econometrics of program evaluation." Journal of Economic Literature 47: 5-86.

Ivashina, V., and Scharfstein, D. (2010). "Bank lending during the financial crisis of 2008." Journal of Financial Economics 97: 319-338.

Jiménez, G. Mian, A. Peydró, J.L., and Saurina, J. (2019) "The real effects of the bank lending channel." Journal of Monetary Economics 23, 13-57.

Jiménez, G., Ongena, S., Peydró, J.L., Saurina, J. (2017). “Macroprudential policy, countercyclical bank capital buffers, and credit supply: Evidence from the Spanish dynamic provisioning experiments." Journal of Political Economy, 125: 2126-2177.

Khwaja, A. and Mian, A. (2008). "Tracing the impact of bank liquidity shocks: Evidence from an emerging market.” American Economic Review, 98 (4): 1413-1442.

Laeven, L. and Majnoni, G. (2003) "Loan loss provisioning and economic slowdowns: too much, too late?” Journal of Financial Intermediation 12 (2003): 178-197.

Liu, C. and Ryan, S. (1995) "The effect of bank loan portfolio composition on the market reaction to and anticipation of provisions for loan losses." Journal of Accounting Research 33: 77-94. 
Liu, C., Ryan, S. and Wahlen, J. (1997) "Differential valuation implications of loan loss provisions across banks and fiscal quarters." The Accounting Review 72: 133-146.

López-Espinosa, G., Ormazabal, G., and Sakasai, Y. (2020). "Switching from incurred to expected credit losses: Early evidence.” IESE working paper.

Löw, E., Schmidt, L., and Thiel, L. (2019) “Accounting for financial instruments under IFRS9First-time application effects on European banks' balance sheets." European Banking Institute Working Paper Series 2019, No. 48.

Lu, Y. and Nikolaev, V., (2019) "Expected loan loss provisioning: An empirical model." Chicago Booth Research Paper No. 19-11.

Maddaloni, A., and Peydró, J.L. (2011). "Bank risk-taking, securitization, supervision, and low interest rates: Evidence from the euro-area and the U.S. lending standards." Review of Financial Studies 24 (6), 2121-2165.

Mathieux, L., Sapra, H., and Zhang, G. (2020). "CECL: Timely loan loss provisioning and bank regulation.” SSRN Working paper, No. 3523321.

Nicoletti, A. (2018) "The effects of bank regulators and external auditors on loan loss provisions." Journal of Accounting and Economics 66: 244-265.

Rajan, R. (2005). "Has financial development made the world riskier?," Proceedings - Economic Policy Symposium - Jackson Hole, Federal Reserve Bank of Kansas City, issue Aug, pages 313369.

Rajan, R. and Winton, A. (1995). "Covenants and collateral as incentives to monitor." Journal of Finance, 50, 1113-1146.

Ryan, S. (2011) "Financial reporting for financial instruments." Foundations and Trends in Accounting 6: 187-354.

SFC (1999). External Circular 039, Superintendencia Financiera de Colombia, Bogotá.

SFC (2004). External Circular 052: Sistema de Administracion de Riesgo de Credito (SARC), Superintendencia Financiera de Colombia, Bogotá.

Stiglitz, J. and Weiss, A. (1981). "Credit rationing in markets with imperfect information." American Economic Review 71: 393-410.

Tommy, R., (2019) "Threat of entry and the use of discretion in banks' financial reporting." Journal of Accounting and Economics 67: 1-35.

Wahlen, J. (1994) "The nature of information in commercial bank loan loss disclosures." The Accounting Review 69: 455-478. 


\section{Table 1. Summary Statistics (Loan, Firm, and Bank Level Variables)}

This table reports the summary statistics of the variables used in our tests. The variables are defined at three levels: "loan-level" (i.e., firm-bank-quarter), "firm-level" (i.e., firm-year), and "bank-level" (i.e., bank-quarter). The loan-level variables are obtained from the credit registry of the Superintendencia Financiera de Colombia (i.e., the Colombian Financial Supervisor). The firm-level variables are obtained from the Superintendencia de Sociedades (i.e., the Colombian equivalent to the United States' Securities and Exchange Commission). The bank-level variables are obtained from the banks' regulatory filings. Detailed variable definitions are provided in Table A1.

\begin{tabular}{|c|c|c|c|c|c|c|}
\hline & Observations & Average & p10 & Median & p90 & Standard Deviation \\
\hline \multicolumn{7}{|l|}{ Loan-level: } \\
\hline Value $_{f, b, q}$ & 41,354 & 57 & 1.6 & 31 & 144 & 76 \\
\hline Provisions $_{f, b, q}$ & 41,348 & 3.4 & 0.63 & 1 & 4.3 & 9.1 \\
\hline${\text { Interest } \text { Rate }_{f, b, q}}$ & 40,465 & 20 & 13 & 20 & 28 & 5.8 \\
\hline Maturity $_{f, b, q}$ & 41,422 & 1.9 & 0.2 & 1.1 & 3.7 & 2.9 \\
\hline Collateral $_{f, b, q}$ & 41,353 & 20 & 0 & 0 & 79 & 32 \\
\hline Arrears $_{f, b, q}$ & 41,353 & 23 & 0 & 0 & 100 & 42.2 \\
\hline Default $_{f, b, q}$ & 41,676 & 1 & 0 & 0 & 0 & 9.4 \\
\hline Small Firm $_{f, b, q}$ & 41,354 & 0.84 & 0 & 1 & 1 & 0.36 \\
\hline \multicolumn{7}{|l|}{ Firm-level: } \\
\hline $\operatorname{Loans}_{f, y}$ & 8,073 & 74 & 0.069 & 34 & 203 & 107 \\
\hline $\operatorname{Assets}_{f, y}$ & 8,073 & 845 & 307 & 728 & 1,555 & 509 \\
\hline Liabilities $f, y$ & 8,073 & 463 & 118 & 368 & 923 & 369 \\
\hline Sales $f, y_{1}$ & 8,018 & 1,606 & 290 & 1,096 & 3,247 & 1,930 \\
\hline Years of Creditt,y & 8,073 & 4.2 & 2 & 4 & 7 & 1.7 \\
\hline \multicolumn{7}{|l|}{ Bank-level: } \\
\hline $\operatorname{Assets~}_{b, q}$ & 41,354 & 19,014 & 4,959 & 19,917 & 330,28 & 9,622 \\
\hline Solvency $_{b, q}$ & 41,354 & 0.14 & 0.11 & 0.13 & 0.16 & 0.02 \\
\hline $\operatorname{Loans}_{b, q}$ & 135 & 8.4 & 7.7 & 8.3 & 9.5 & 0.72 \\
\hline TangibilitySector $_{b, q}$ & 135 & 0.19 & 0.19 & 0.19 & 0.2 & 0.01 \\
\hline RiskSector $_{b, q}$ & 135 & 0.2 & 0.2 & 0.2 & 0.21 & 0.004 \\
\hline CreditHistory $_{b, q}$ & 135 & 1.3 & 0.84 & 1.4 & 1.7 & 0.33 \\
\hline Herfindahl Firms & 135 & 0.05 & 0.00 & 0.01 & 0.11 & 0.11 \\
\hline Herfindahl Sector $b, q$ & 135 & 0.11 & 0.06 & 0.07 & 0.13 & 0.10 \\
\hline
\end{tabular}




\section{Table 2. Comparison of Smaller and Larger Borrowers}

This table compares the summary statistics of Smaller and Larger firms in 2007Q2 (i.e., the quarter before the implementation of SARC). The sample includes all borrowing firms with assets, in 2005, between COP 1.5 billion and COP 4.5 billion (i.e., roughly USD 0.75 million and 1.5 million). Smaller refers to sample firms classified as "small-size" ("pequeñas") by the Law 905 (i.e., firms with COP 1.5 billion $<$ total assets $<$ COP 2.1 billion). Larger refers to sample firms classified as "medium-size" ("medianas") by the Law 905 (i.e., firms with COP $2.1<$ total assets $<$ COP 4.5 billion). The number of Smaller and Larger firms is 898 and 598, respectively. The variables are defined at three levels: "loan-level" (i.e., firm-bank-quarter), "firm-level" (i.e., firm-year), and "bank-level" (i.e., bank-quarter). The results in the last column—NormDiff- are the normalized differences (based on Imbens and Wooldridge, 2009) and all differences are insignificant. Detailed variable definitions are provided in Table A1.

\begin{tabular}{|c|c|c|c|c|c|c|}
\hline & \multicolumn{2}{|c|}{ Smaller Firms } & \multicolumn{2}{|c|}{ Larger Firms } & \multicolumn{2}{|c|}{ Comparison } \\
\hline & Mean & Std. Deviation & Mean & Std. Deviation & Diff & NormDiff \\
\hline \multicolumn{7}{|l|}{ Loan-Level: } \\
\hline$\overline{\text { Provisions }_{f, b, 2007 Q 2}}$ & 1.3 & 4.1 & 1.4 & 5.7 & 0.0 & 0.04 \\
\hline Value $_{f, b, 2007 Q 2}$ & 57.8 & 68.4 & 56.0 & 80.5 & 1.8 & 0.01 \\
\hline Interest Rate $_{f, b, 2007 Q 2}$ & 18.3 & 3.6 & 18.7 & 3.5 & -0.4 & -0.01 \\
\hline Collateral $_{f, b, 2007 Q 2}$ & 25.4 & 31.7 & 21.0 & 31.2 & 4.4 & -0.01 \\
\hline Years Credit $f, 2007 Q 2$ & 5.4 & 1.5 & 5.5 & 1.4 & -0.1 & -0.02 \\
\hline \multicolumn{7}{|l|}{ Firm-Level: } \\
\hline$\overline{\text { Value }_{f, 2006}}$ & 118.8 & 136.8 & 141.1 & 217.2 & -22.3 & 0.00 \\
\hline Assets $_{f, 2006}$ & 914.8 & 463.1 & 1282.4 & 948.9 & -367.5 & 0.00 \\
\hline Liabilities $_{f, 2006}$ & 518.7 & 337.2 & 744.6 & 675.8 & -225.9 & 0.00 \\
\hline \multicolumn{7}{|l|}{ Bank-Level: } \\
\hline Solvency $b, 2007 Q 2$ & 12.7 & 2.1 & 12.4 & 2.1 & 0.3 & -0.04 \\
\hline$R O A_{b, 2007 Q 2}$ & 2.2 & 0.4 & 2.2 & 0.4 & 0.0 & 0.01 \\
\hline Loans Default ${ }_{b, 2007 Q 2}$ & 4.2 & 0.9 & 4.3 & 1.1 & -0.1 & -0.02 \\
\hline
\end{tabular}




\section{Table 3. Determinants of Bank Provisions}

This table reports the results of the determinants of bank provisions. The analysis is conducted at the loan-level (i.e., bank-firm-quarter) including the quarters immediately before and after the implementation of the new provisioning scheme. The dependent variable in columns (1)-(3), Provisions $f, b, q$, is defined as the rate of provisions of the loan(s) given to firm $f$ by bank $b$ in quarter $q$. Columns (1) and (2) include observations in the quarter prior (2007Q2) and subsequent (2007Q3) to the implementation of the new provisioning scheme. Column (3) pools observations from 2007Q2 and 2007Q3. The dependent variable in columns (4)-(5), Default t,b,q is an indicator variable

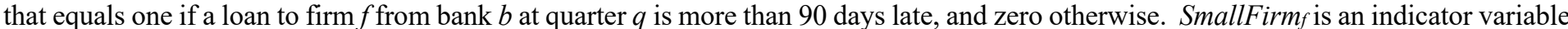
that equals one if the firm is classified as "small" by Law 905 at the start of the sample period, and zero otherwise. Collateral $f, b, q$ is the percentage of loan value (to firm $f$ from bank $b$ at quarter $q$ ) covered by guarantees. Latef,b,q is an indicator variable that equals one if a loan (to firm $f$ from bank $b$ at quarter $q$ ) is in arrears, and zero otherwise. Standard errors (in parentheses) are double-clustered at the firmbank and quarter level. $* * * \mathrm{p}<0.01, * * \mathrm{p}<0.05, * \mathrm{p}<0.1$. Detailed variable definitions are provided in Table A1.

\begin{tabular}{|c|c|c|c|c|c|}
\hline & \multicolumn{3}{|c|}{ Provision $_{f, b, q}$} & \multicolumn{2}{|c|}{ Default $_{f, b, q}$} \\
\hline & $\begin{array}{c}2007 Q^{2} \\
(1)\end{array}$ & $\begin{array}{c}2007 \mathrm{Q3} \\
(2)\end{array}$ & $\begin{array}{c}\text { Both periods } \\
(3)\end{array}$ & $\begin{array}{c}\text { Both periods } \\
(4)\end{array}$ & $\begin{array}{c}\text { Both periods } \\
\text { (5) }\end{array}$ \\
\hline \multirow[t]{2}{*}{ Post $_{q}$} & & & $2.41^{* * *}$ & 0.00 & 0.00 \\
\hline & & & $(0.15)$ & $(0.00)$ & $(0.00)$ \\
\hline \multirow[t]{2}{*}{ SmallFirm $_{f}$} & 0.01 & $0.95^{* * *}$ & 0.01 & $0.01^{* * *}$ & $0.01^{* * *}$ \\
\hline & $(0.11)$ & $(0.15)$ & $(0.11)$ & $(0.00)$ & $(0.00)$ \\
\hline \multirow[t]{2}{*}{ SmallFirm $_{f} *$ Post $_{q}$} & & & $0.93^{* * *}$ & 0.00 & 0.00 \\
\hline & & & $(0.19)$ & $(0.00)$ & $(0.00)$ \\
\hline \multirow[t]{2}{*}{ Collateral $_{f, b, q}$} & -0.11 & $-1.31^{* * *}$ & -0.11 & & 0.00 \\
\hline & $(0.10)$ & $(0.20)$ & $(0.10)$ & & $(0.00)$ \\
\hline \multirow[t]{2}{*}{ Collateral $_{f, b, q}{ }^{*}$ Post $_{q}$} & & & $-1.20^{* * *}$ & & 0.01 \\
\hline & & & $(0.22)$ & & $(0.01)$ \\
\hline \multirow[t]{2}{*}{ Late $_{f, b, q}$} & 0.15 & $0.38^{*}$ & 0.15 & & \\
\hline & $(0.11)$ & $(0.20)$ & $(0.11)$ & & \\
\hline \multirow[t]{2}{*}{ Late $_{f, b, q} *$ Post $_{q}$} & & & 0.23 & & \\
\hline & & & $(0.23)$ & & \\
\hline Observations & 4,477 & 4,521 & 8,998 & 9,003 & 8,998 \\
\hline R-squared & 0.004 & 0.026 & 0.087 & 0.001 & 0.057 \\
\hline
\end{tabular}




\section{Table 4. Credit Supply and Borrower Size}

This table reports the results of an analysis of loan conditions around the implementation of SARC based on borrower size. The analysis is conducted at the loan-level (i.e., bank-firm-quarter) including four quarters immediately before and after the implementation of the new provisioning scheme (i.e., from 2006Q2 to 2008Q2). Valuef,b,q is the log of loan value (measured in pesos), Interest Ratef,b,q is the loan interest rate (measured in percent), Maturityf,b,q is the log of loan maturity (measured in years). SmallFirm $f$ is an indicator that equals one if the firm was classified as "small" by Law 905 at the start of the sample period, and zero otherwise. Post $q$ is an indicator that the observation is after the implementation of the new provisioning scheme in 2007Q2. Standard errors (in parentheses) are double clustered at the firm-bank and quarter level. $* * * \mathrm{p}<0.01, * * \mathrm{p}<0.05, * \mathrm{p}<0.1$. Detailed variable definitions are provided in Table A1.

\begin{tabular}{|c|c|c|c|c|c|c|c|c|c|}
\hline & \multicolumn{3}{|c|}{ Value $_{f, b, q}$} & \multicolumn{3}{|c|}{ Interest Rate $_{f, b, q}$} & \multicolumn{3}{|c|}{ Maturity $_{f, b, q}$} \\
\hline & (1) & (2) & (3) & (4) & (5) & (6) & $(7)$ & (8) & (9) \\
\hline \multirow{2}{*}{ SmallFirm $_{f}^{*}$ Post $_{q}$} & $-0.17^{* *}$ & $-0.14^{* *}$ & $-0.17^{* * *}$ & $2.78^{* * *}$ & $0.51^{* *}$ & $0.46^{*}$ & -0.02 & $-0.06^{* * *}$ & $-0.06^{* *}$ \\
\hline & $(0.07)$ & $(0.06)$ & $(0.06)$ & $(0.22)$ & $(0.22)$ & $(0.24)$ & $(0.02)$ & $(0.02)$ & $(0.03)$ \\
\hline Observations & 34,921 & 34,900 & 34,900 & 30,097 & 30,063 & 30,097 & 31,853 & 31,827 & 31,853 \\
\hline R-squared & 0.77 & 0.77 & 0.79 & 0.61 & 0.71 & 0.74 & 0.74 & 0.74 & 0.76 \\
\hline Firm-Bank FE & Yes & Yes & Yes & Yes & Yes & Yes & Yes & Yes & Yes \\
\hline Bank-Quarter FE & No & Yes & Yes & No & Yes & Yes & No & Yes & Yes \\
\hline Region-Sector-Quarter FE & No & No & Yes & No & No & Yes & No & No & Yes \\
\hline
\end{tabular}




\section{Table 5. Credit Supply and Collateralizability}

This table reports the results of an analysis of loan conditions around the implementation of SARC based on the tangibility of assets in the borrower's sector. The analysis is conducted at the loan-level (i.e., bank-firm-quarter) including four quarters immediately before and after the implementation of the new provisioning scheme (i.e., from 2006Q2 to 2008Q2). Valuef,b,q is the log of loan value (measured in pesos), Interest Ratef,b,q is the loan interest rate (measured in percent), Maturityf,b,q is the log of loan maturity (measured in years). TangibleSectors is an indicator variable that equals one if the tangibility ratio of a sector - measured as the average ratio of fixed assets to total assets - is above the sample median, and zero otherwise. Post $t_{q}$ is an indicator that the observation is after the implementation of the new provisioning scheme in 2007Q2. SmallFirm $f$ is an indicator that equals one if the firm was classified as "small" by Law 905 at the start of the sample period, and zero otherwise. Standard errors (in parentheses) are double clustered at the firm-bank and quarter level. $* * * \mathrm{p}<0.01, * * \mathrm{p}<0.05, * \mathrm{p}<0.1$. Detailed variable definitions are provided in Table A1.

\begin{tabular}{|c|c|c|c|c|c|c|}
\hline & \multicolumn{2}{|c|}{ Value $_{f, b, q}$} & \multicolumn{2}{|c|}{ Interest Rate $_{f, b, q}$} & \multicolumn{2}{|c|}{ Maturity $_{f, b, q}$} \\
\hline & (1) & (2) & (3) & (4) & $(5)$ & $(6)$ \\
\hline \multirow[t]{2}{*}{ TangibleSector ${ }^{*}$ Post $_{q}$} & -0.03 & & 0.03 & & -0.01 & \\
\hline & $(0.03)$ & & $(0.13)$ & & $(0.01)$ & \\
\hline \multirow[t]{2}{*}{ SmallFirm $_{f}^{*}$ Post $_{q}$} & $-0.06^{*}$ & -0.06 & $0.51^{* * *}$ & $0.50^{* * *}$ & -0.01 & -0.01 \\
\hline & $(0.04)$ & $(0.04)$ & $(0.15)$ & $(0.16)$ & $(0.02)$ & $(0.02)$ \\
\hline \multirow{2}{*}{ TangibleSector $_{s}{ }^{*}$ SmallFirm $_{f} *$ Post $_{q}$} & $0.13^{*}$ & $0.13^{*}$ & $-0.37^{*}$ & $-0.47^{*}$ & -0.03 & -0.03 \\
\hline & $(0.07)$ & $(0.07)$ & -0.21 & -0.28 & $(0.03)$ & $(0.03)$ \\
\hline Observations & 34,921 & 34,900 & 30,097 & 30,063 & 31,853 & 31,827 \\
\hline R-squared & 0.79 & 0.80 & 0.72 & 0.73 & 0.71 & 0.71 \\
\hline Firm-Bank FE & Yes & Yes & Yes & Yes & Yes & Yes \\
\hline Bank-Quarter FE & Yes & Yes & Yes & Yes & Yes & Yes \\
\hline Industry-Quarter FE & No & Yes & No & Yes & No & Yes \\
\hline
\end{tabular}




\section{Table 6. Credit Supply and Delinquency}

This table reports the results of an analysis of loan conditions around the implementation of SARC based on borrower delinquency. The analysis is conducted at the loan-level (i.e., bank-firm-quarter) including four quarters immediately before and after the implementation of the new provisioning scheme (i.e., from $2006 \mathrm{Q} 2$ to 2008Q2). Value $f, b, q$ is the log of loan value (measured in pesos), Interest Ratef,b,q is the loan interest rate (measured in percent), Maturity $f, b, q$ is the log of loan maturity (measured in years). SmallFirm $f$ is an indicator that equals one if the firm was classified as "small" by Law 905 at the start of the sample period, and zero otherwise. Post $t_{q}$ is an indicator variable that equals one if the observation is after the implementation of the new provisioning scheme in 2007Q2, and zero otherwise. Smaller Borrowers (Larger Borrowers) refer to the subsample of firms classified as "small" ("medium") by Law 905 at the start of the sample period. Default $f, b, q$ is an indicator that the outstanding loan that firm $f$ holds from bank $b$ in quarter $q$ is more than 90 days in arrears. Post $t_{q}$ is an indicator that equals one if the observation is after the implementation of the new provisioning scheme in 2007Q2, and zero otherwise. Sample period from 2006Q2 to 2008Q2. Standard errors (in parentheses) are double clustered at the firmbank and quarter level. $* * * \mathrm{p}<0.01, * * \mathrm{p}<0.05, * \mathrm{p}<0.1$. Detailed variable definitions are provided in Table A1.

\begin{tabular}{|c|c|c|c|c|c|c|}
\hline & \multicolumn{2}{|c|}{ Value $_{f, b, q}$} & \multicolumn{2}{|c|}{ Interest Rate $_{f, b, q}$} & \multicolumn{2}{|c|}{ Maturity $_{f, b, q}$} \\
\hline & $\begin{array}{c}\text { Smaller } \\
\text { Borrowers } \\
(1)\end{array}$ & $\begin{array}{c}\text { Larger } \\
\text { Borrowers } \\
(2)\end{array}$ & $\begin{array}{c}\text { Smaller } \\
\text { Borrowers } \\
\text { (3) }\end{array}$ & $\begin{array}{c}\text { Larger } \\
\text { Borrowers } \\
(4)\end{array}$ & $\begin{array}{c}\text { Smaller } \\
\text { Borrowers } \\
(5)\end{array}$ & $\begin{array}{c}\text { Larger } \\
\text { Borrowers } \\
(6)\end{array}$ \\
\hline Default $_{f, b, q}$ & $\begin{array}{c}0.40 \\
(0.28)\end{array}$ & $\begin{array}{l}-0.25 \\
(0.40)\end{array}$ & $\begin{array}{l}-0.17 \\
(1.27)\end{array}$ & $\begin{array}{c}0.53 \\
(1.11)\end{array}$ & $\begin{array}{l}-0.07 \\
(0.13)\end{array}$ & $\begin{array}{l}-0.34 \\
(0.24)\end{array}$ \\
\hline Default $^{*}$ Post $_{q}$ & $\begin{array}{c}-0.58^{* * *} \\
(0.15)\end{array}$ & $\begin{array}{l}-0.00 \\
(0.42)\end{array}$ & $\begin{array}{c}0.22 \\
(1.93)\end{array}$ & $\begin{array}{l}-0.34 \\
(1.85)\end{array}$ & $\begin{array}{l}-0.27^{*} \\
(0.17)\end{array}$ & $\begin{array}{c}0.22 \\
(0.24)\end{array}$ \\
\hline Observations & 6,686 & 19,975 & 5,816 & 17,473 & 6,108 & 18,385 \\
\hline R-squared & 0.77 & 0.77 & 0.69 & 0.71 & 0.69 & 0.73 \\
\hline Firm-Bank FE & Yes & Yes & Yes & Yes & Yes & Yes \\
\hline Bank-Quarter FE & Yes & Yes & Yes & Yes & Yes & Yes \\
\hline
\end{tabular}




\section{Table 7. Real Effects (Firm Outcomes)}

This table reports the results of an analysis of firm outcomes around the implementation of SARC. The analysis is conducted at the firm-level (i.e., bank-year) including observations from 2005 to 2007 using firm $f$ level outcomes in year $y$. Loans,y is the logarithm of the value of total outstanding loans (measured in pesos) of firm $f$ in year $y$. Liabilities $f, y$, Assets $f, y_{\text {and Salesf,y }}$ are, respectively, the logarithm of the total liabilities (including bank loans), assets, and revenues (all three measured in Colombian pesos) of firm $f$ in year $y$. Pre $y$ is an indicator variable that equals one if the borrower's yearly balance sheet value is in 2005, and zero otherwise. Posty is an indicator variable that equals one if the borrower's yearly balance sheet value is in 2007, and zero otherwise. SmallFirm $f$ is an indicator that equals one if the firm was classified as "small" by Law 905 at the start of the sample period, and zero otherwise. In the fixed effects structure, "Mainbank" refers to the bank that holds the highest percentage of the aggregated value of the firm's loans. Standard errors (in parentheses) are double clustered at the firm level. ${ }^{* * *} \mathrm{p}<0.01,{ }^{* *} \mathrm{p}<0.05,{ }^{*} \mathrm{p}<0.1$. Detailed variable definitions are provided in Table A1.

\begin{tabular}{|c|c|c|c|c|}
\hline & $\begin{array}{c}\operatorname{Loans}_{f, y} \\
(1)\end{array}$ & $\begin{array}{c}\text { Liabilities }_{f, y} \\
\text { (2) }\end{array}$ & $\begin{array}{c}\operatorname{Assets}_{f, y} \\
\text { (3) }\end{array}$ & $\begin{array}{c}\text { Sales }_{f, y} \\
(4)\end{array}$ \\
\hline \multirow[t]{2}{*}{ SmallFirm $_{f}^{*}$ Pre $_{y}$} & -0.07 & $0.09^{*}$ & -0.08 & -0.01 \\
\hline & $(0.16)$ & $(0.04)$ & $(0.05)$ & $(0.10)$ \\
\hline \multirow[t]{2}{*}{ SmallFirm $_{f}^{*}$ Post $_{y}$} & $-0.30^{* *}$ & $-0.30^{* * *}$ & $-0.21^{* * *}$ & $-0.12^{*}$ \\
\hline & $(0.12)$ & $(0.03)$ & $(0.02)$ & $(0.05)$ \\
\hline Observations & 5,217 & 5,217 & 4,155 & 4,155 \\
\hline R-squared & 0.86 & 0.92 & 0.84 & 0.84 \\
\hline Firm FE & Yes & Yes & Yes & Yes \\
\hline MainBank*Year FE & Yes & Yes & Yes & Yes \\
\hline State*Industry*Year FE & Yes & Yes & Yes & Yes \\
\hline
\end{tabular}




\section{Table 8. Bank Insolvency Risk and Avoidance of Risky Sectors}

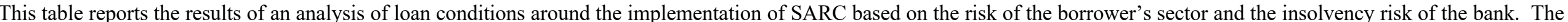

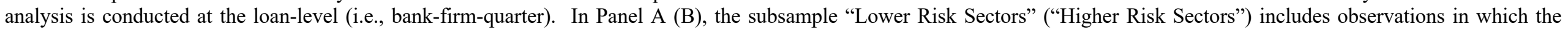

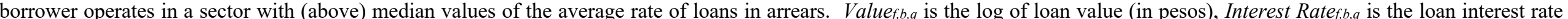

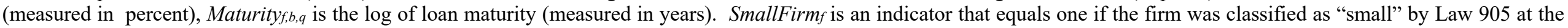

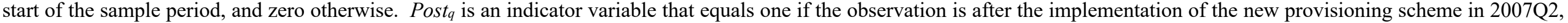

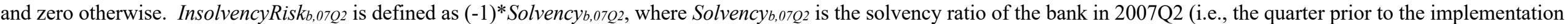

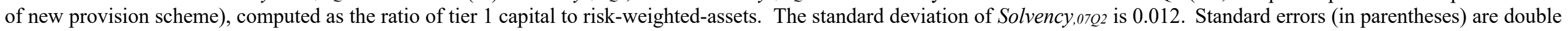
clustered at the firm-bank and quarter level. $* * * \mathrm{p}<0.01, * * \mathrm{p}<0.05, * \mathrm{p}<0.1$. Detailed variable definitions are provided in Table A1.

\begin{tabular}{|c|c|c|c|c|c|c|c|c|c|}
\hline \multirow[t]{2}{*}{ Panel A. Lower Risk Sectors } & \multicolumn{3}{|c|}{ Valuef $, b, q$} & \multicolumn{3}{|c|}{ Interest Ratef,b,q } & \multicolumn{3}{|c|}{ Maturity $f, b, q$} \\
\hline & $(1)$ & $(2)$ & (3) & (4) & $(5)$ & $(6)$ & $(7)$ & $(8)$ & (9) \\
\hline \multirow[t]{2}{*}{ SmallFirm $_{f} *$ Post $_{q}$} & -0.02 & -0.02 & & $0.63^{* * *}$ & $0.60^{* * *}$ & & -0.02 & -0.01 & \\
\hline & $(0.04)$ & $(0.04)$ & & $(0.20)$ & $(0.21)$ & & $(0.02)$ & $(0.02)$ & \\
\hline \multirow[t]{2}{*}{ SmallFirm $_{f} *$ Post $_{q} *$ InsolvencyRisk $_{b, 07 Q 2}$} & & -0.78 & 3.66 & & 10.70 & 19.51 & & $-3.78^{* *}$ & $-5.07^{* *}$ \\
\hline & & $(3.43)$ & $(4.45)$ & & (14.94) & $(23.88)$ & & $(1.52)$ & $(2.03)$ \\
\hline Observations & 20,656 & 20,656 & 12,195 & 18,192 & 18,192 & 9,942 & 18,915 & 18,915 & 10,861 \\
\hline R-squared & 0.82 & 0.82 & 0.89 & 0.74 & 0.74 & 0.83 & 0.72 & 0.72 & 0.85 \\
\hline Firm-Bank FE & Yes & Yes & Yes & Yes & Yes & Yes & Yes & Yes & Yes \\
\hline Bank-Quarter FE & Yes & Yes & Yes & Yes & Yes & Yes & Yes & Yes & Yes \\
\hline State-Industry-Quarter FE & Yes & Yes & - & Yes & Yes & - & Yes & Yes & - \\
\hline Firm-Quarter FE & No & No & Yes & No & No & Yes & No & No & Yes \\
\hline \multicolumn{10}{|l|}{ Panel B. Higher Risk Sectors } \\
\hline & \multicolumn{3}{|c|}{ Value $_{f, b, q}$} & \multicolumn{3}{|c|}{ Interest Ratef,b,q } & \multicolumn{3}{|c|}{ Maturity $f, b, q$} \\
\hline & $(1)$ & $(2)$ & (3) & $(4)$ & $(5)$ & (6) & $(7)$ & $(8)$ & (9) \\
\hline \multirow[t]{2}{*}{ SmallFirm $_{f}^{* \text { Post }_{q}}$} & $-0.12^{* * *}$ & $-0.12^{* * *}$ & & $0.97^{* * *}$ & $0.92^{* * *}$ & & -0.03 & -0.03 & \\
\hline & $(0.05)$ & $(0.05)$ & & $(0.21)$ & $(0.21)$ & & $(0.02)$ & $(0.02)$ & \\
\hline \multirow[t]{2}{*}{ SmallFirm $_{f} *$ Post $_{q} *$ InsolvencyRisk $_{b, 07 Q 2}$} & & $-6.49^{* *}$ & $-6.99^{*}$ & & $26.68^{*}$ & 17.39 & & $-3.66^{* * *}$ & $-3.19^{*}$ \\
\hline & & $(3.11)$ & $(4.21)$ & & $(15.93)$ & $(24.11)$ & & $(1.36)$ & $(1.83)$ \\
\hline Observations & 20,390 & 20,390 & 12,178 & 17,915 & 17,915 & 9,951 & 18,427 & 18,427 & 10,467 \\
\hline R-squared & 0.81 & 0.81 & 0.89 & 0.74 & 0.74 & 0.85 & 0.77 & 0.77 & 0.87 \\
\hline Firm-Bank FE & Yes & Yes & Yes & Yes & Yes & Yes & Yes & Yes & Yes \\
\hline Bank-Quarter FE & Yes & Yes & Yes & Yes & Yes & Yes & Yes & Yes & Yes \\
\hline State-Industry-Quarter FE & Yes & Yes & - & Yes & Yes & - & Yes & Yes & - \\
\hline Firm-Quarter FE & No & No & Yes & No & No & Yes & No & No & Yes \\
\hline
\end{tabular}




\section{Table 9. Bank Insolvency Risk and "Search for Yield"}

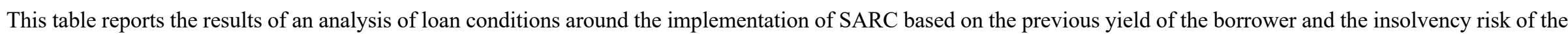

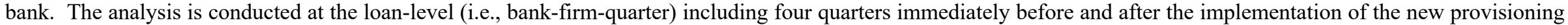

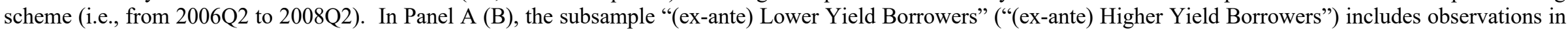

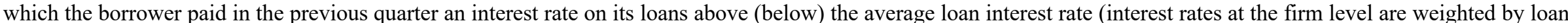

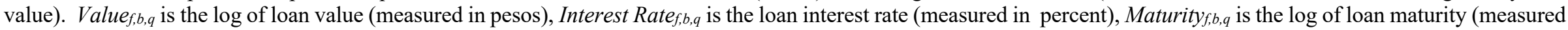

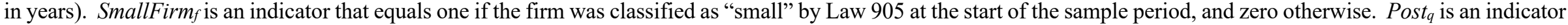

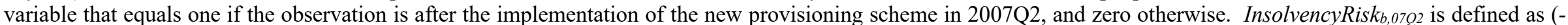

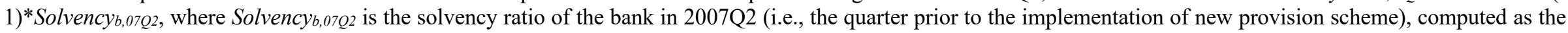

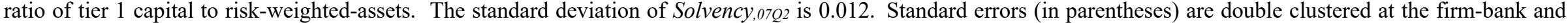
quarter level. $* * * \mathrm{p}<0.01, * * \mathrm{p}<0.05, * \mathrm{p}<0.1$. Detailed variable definitions are provided in Table A1

\begin{tabular}{|c|c|c|c|c|c|c|}
\hline \multicolumn{7}{|c|}{ Panel A. (ex-ante) Lower Yield borrowers } \\
\hline & \multicolumn{2}{|c|}{ Value $f, b, q$} & \multicolumn{2}{|c|}{ Interest Ratef,b,q } & \multicolumn{2}{|c|}{ Maturityf,b,q } \\
\hline & $(1)$ & $(2)$ & (3) & (4) & $(5)$ & $(6)$ \\
\hline \multirow[t]{2}{*}{ SmallFirm $_{f}^{* P_{\text {Ost }}}{ }_{q}$} & $-0.06^{*}$ & & $0.76^{* *}$ & & -0.01 & \\
\hline & $(0.03)$ & & $(0.35)$ & & $(0.01)$ & \\
\hline \multirow[t]{2}{*}{ SmallFirm $_{f} *$ Post $_{q}{ }^{*}$ InsolvencyRisk ${ }_{b, 07 Q 2}$} & $-8.11^{* *}$ & $-9.00^{* *}$ & 3.28 & 10.90 & $-5.86^{* * *}$ & $-6.47^{* * *}$ \\
\hline & $(3.48)$ & $(3.71)$ & $(11.42)$ & $(20.11)$ & $(0.86)$ & $(1.85)$ \\
\hline Observations & 33,817 & 16,693 & 28,997 & 12,852 & 30,744 & 14,383 \\
\hline R-squared & 0.82 & 0.89 & 0.75 & 0.86 & 0.74 & 0.87 \\
\hline Firm-Bank FE & Yes & Yes & Yes & Yes & Yes & Yes \\
\hline Bank-Quarter FE & Yes & Yes & Yes & Yes & Yes & Yes \\
\hline State-Industry-Quarter FE & Yes & - & Yes & - & Yes & - \\
\hline Firm-Quarter FE & No & Yes & No & Yes & No & Yes \\
\hline \multicolumn{7}{|c|}{ Panel B. (ex-ante) Higher Yield borrowers } \\
\hline & \multicolumn{2}{|c|}{ Value $_{f, b, q}$} & \multicolumn{2}{|c|}{ Interest Ratef,b,q } & \multicolumn{2}{|c|}{ Maturity $_{f, b, q}$} \\
\hline & $(1)$ & $(2)$ & $(3)$ & (4) & $(5)$ & $(6)$ \\
\hline \multirow[t]{2}{*}{ SmallFirmf $_{f}^{*}$ Post $_{q}$} & -0.08 & & 0.16 & & -0.02 & \\
\hline & $(0.06)$ & & $(0.38)$ & & $(0.02)$ & \\
\hline \multirow[t]{2}{*}{ SmallFirm $_{f} *$ Post $_{q} *$ InsolvencyRisk ${ }_{b, 07 Q 2}$} & 2.46 & $19.29^{* * *}$ & $33.76^{* *}$ & $50.90^{*}$ & $-1.98^{* * *}$ & -1.49 \\
\hline & $(3.10)$ & $(3.60)$ & $(11.41)$ & $(23.93)$ & $(0.59)$ & $(3.51)$ \\
\hline Observations & 10,629 & 2,031 & 10,084 & 1,825 & 9,603 & 1,688 \\
\hline R-squared & 0.81 & 0.91 & 0.69 & 0.84 & 0.77 & 0.90 \\
\hline Firm-Bank FE & Yes & Yes & Yes & Yes & Yes & Yes \\
\hline Bank-Quarter FE & Yes & Yes & Yes & Yes & Yes & Yes \\
\hline State-Industry-Quarter FE & Yes & - & Yes & - & Yes & - \\
\hline Firm-Quarter FE & No & Yes & No & Yes & No & Yes \\
\hline
\end{tabular}




\section{Table 10. Bank Insolvency Risk and Portfolio Composition}

This table reports the results of an analysis of bank loan portfolio composition around SARC based on the insolvency risk of the bank. The analysis is conducted at the bank-level (i.e., bank- quarter) including four quarters immediately before and after the implementation of the new provisioning scheme (i.e., from 2006Q2 to 2008Q2). Loansb,q is the total value of outstanding loans for bank $b$ in quarter $q$. TangibilitySectorb, $q$ is the average tangibility (measured as the ratio of fixed assets to total assets) of the sectors of bank $b$ 's borrowers in quarter $q$. Similarly, RiskSectorb,q is the weighted average rate of defaulted loans (i.e., loans in arrears for more than 90 days) of the sectors of bank $b$ 's borrowers in quarter $q$. CreditHistory,$q$ is the average years of a bank's credit relation with its borrowers, weighted by loan value. Post $q$ is an indicator variable that equals one if the observation is after the implementation of the new provisioning scheme in $2007 \mathrm{Q} 2$, and zero otherwise. InsolvencyRiskb,07Q2 is defined as (-1)*Solvencyb,07Q2, where Solvencyb,07Q2 is the solvency ratio of the bank in $2007 \mathrm{Q} 2$ (i.e., the quarter prior to the implementation of new provision scheme), computed as the ratio of tier 1 capital to risk-weighted-assets. Standard errors (in parentheses) are clustered at the bank and quarter level. $* * * \mathrm{p}<0.01, * * \mathrm{p}<0.05, * \mathrm{p}<0.1$. Detailed variable definitions are provided in Table A1.

\begin{tabular}{|c|c|c|c|c|c|c|c|c|}
\hline & \multicolumn{2}{|c|}{$\operatorname{Loans}_{b, q}$} & \multicolumn{2}{|c|}{ TangibilitySector $_{b, q}$} & \multicolumn{2}{|c|}{ RiskSector $_{b, q}$} & \multicolumn{2}{|c|}{ CreditHistory $_{b, q}$} \\
\hline & $(1)$ & (2) & (3) & (4) & $(5)$ & (6) & $(7)$ & $(8)$ \\
\hline \multirow[t]{2}{*}{ Post $_{q}$} & -0.07 & & $0.00^{* * *}$ & & $-0.00^{* *}$ & & $0.59^{* * *}$ & \\
\hline & $(0.12)$ & & $(0.00)$ & & $(0.00)$ & & $(0.17)$ & \\
\hline \multirow[t]{2}{*}{ Post $_{q}{ }^{*}$ InsolvencyRisk $k_{b, 07 Q 2}$} & $-2.56^{* *}$ & $-2.56^{* * *}$ & $0.04^{* * *}$ & $0.04^{* * *}$ & $-0.03^{* *}$ & $-0.03^{* *}$ & $3.86^{* * *}$ & $3.86^{* * *}$ \\
\hline & $(1.01)$ & $(0.85)$ & $(0.01)$ & $(0.01)$ & $(0.02)$ & $(0.02)$ & $(1.44)$ & $(1.10)$ \\
\hline Observations & 135 & 135 & 135 & 135 & 135 & 135 & 135 & 135 \\
\hline R-squared & 0.98 & 0.99 & 0.94 & 0.94 & 0.65 & 0.67 & 0.84 & 0.93 \\
\hline Bank FE & Yes & Yes & Yes & Yes & Yes & Yes & Yes & Yes \\
\hline Quarter FE & No & Yes & No & Yes & No & Yes & No & Yes \\
\hline
\end{tabular}




\section{Table 11. Bank Insolvency Risk and Loan Portfolio Concentration}

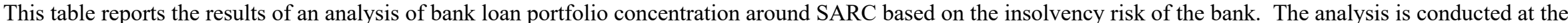

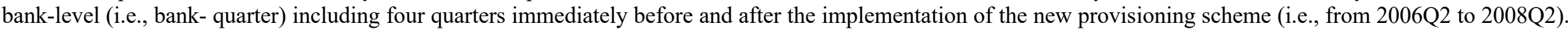

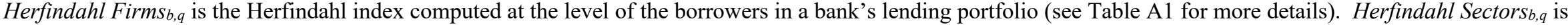

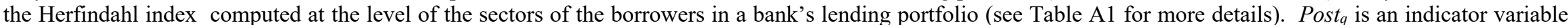

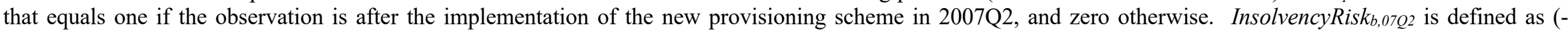
1)*Solvency F, $07 Q 2^{2}$, where Solvencyb,07Q2 is the solvency ratio of the bank in 2007Q2 (i.e., the quarter prior to the implementation of new provision scheme), computed as

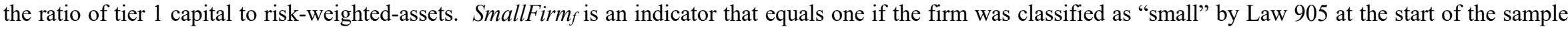

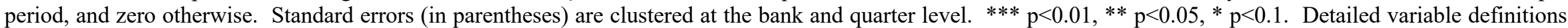
are provided in Table A1.

\begin{tabular}{|c|c|c|c|c|c|c|}
\hline & \multicolumn{3}{|c|}{ Herfindahl Firms $_{b, q}$} & \multicolumn{3}{|c|}{ Herfindahl Sectors $_{b, q}$} \\
\hline & (1) & $(2)$ & (3) & $(4)$ & $(5)$ & $(6)$ \\
\hline \multirow[t]{2}{*}{ Post $_{q}$} & $0.02^{* * *}$ & & & $0.04^{* * *}$ & & \\
\hline & $(0.01)$ & & & $(0.01)$ & & \\
\hline \multirow[t]{2}{*}{ Post $_{q}{ }^{*}$ InsolvencyRisk ${ }_{b, 07 Q 2}$} & $0.21^{* * *}$ & $0.21^{* * *}$ & $-1.09^{* * *}$ & $0.34^{* * *}$ & $0.34^{* * *}$ & $-0.95^{* * *}$ \\
\hline & $(0.07)$ & $(0.07)$ & $(0.33)$ & $(0.08)$ & $(0.08)$ & $(0.32)$ \\
\hline \multirow[t]{2}{*}{ Post $_{q}{ }^{*}$ SmallFirm $_{b, 07 Q 2}$} & & & $0.33^{* * *}$ & & & $0.33^{* * *}$ \\
\hline & & & $(0.10)$ & & & $(0.10)$ \\
\hline \multirow{2}{*}{ Post $_{q} *$ InsolvencyRisk $_{b, 07 Q 2} *$ SmallFirm $_{b, 07 Q 2}$} & & & $2.46^{* * *}$ & & & $2.45^{* * *}$ \\
\hline & & & $(0.69)$ & & & $(0.65)$ \\
\hline Observations & 134 & 134 & 134 & 134 & 134 & 134 \\
\hline R-squared & 0.99 & 0.99 & 0.99 & 0.99 & 0.99 & 0.99 \\
\hline Bank FE & Yes & Yes & Yes & Yes & Yes & Yes \\
\hline Quarter FE & No & Yes & Yes & No & Yes & Yes \\
\hline Average(Herfindahl Firms H $\left._{b, q}\right)$ & 0.042 & 0.042 & 0.042 & 0.042 & 0.042 & 0.042 \\
\hline Average (Herfindahl Sectors $b, q)$ & 0.056 & 0.056 & 0.056 & 0.056 & 0.056 & 0.056 \\
\hline $\mathrm{SD}\left(\right.$ Herfindahl Firms $\left._{b, q}\right)$ & 0.021 & 0.021 & 0.021 & 0.021 & 0.021 & 0.021 \\
\hline $\mathrm{SD}\left(\right.$ Herfindahl Sectors $\left._{b, q}\right)$ & 0.101 & 0.101 & 0.101 & 0.101 & 0.101 & 0.101 \\
\hline
\end{tabular}




\section{Figure 1. Share of Provisions per Groups of Borrowers}

The figure plots the average rate of provisions of loans partitioning the sample based on borrower size (Panel A), loan collateralization (Panel B), and sector riskiness (Panel C). The rate of provisions is computed as the amount of loan loss provisions divided by the value of outstanding loans. The vertical bar in all panels includes the quarters around the implementation of SARC. In Panel A "smaller" ("larger") refers to borrowers classified as "small" ("medium") by Law 905 at the start of the sample period. In Panel B, "Collateral" ("Non-Collateral") refers to loans with (without) collateral. In Panel C, "Higher Risk" ("Lower Risk") refers to sectors with above (below) median percentages of defaulted loans (i.e., loans in arrears at least 90 days)

Panel A. Smaller vs Larger

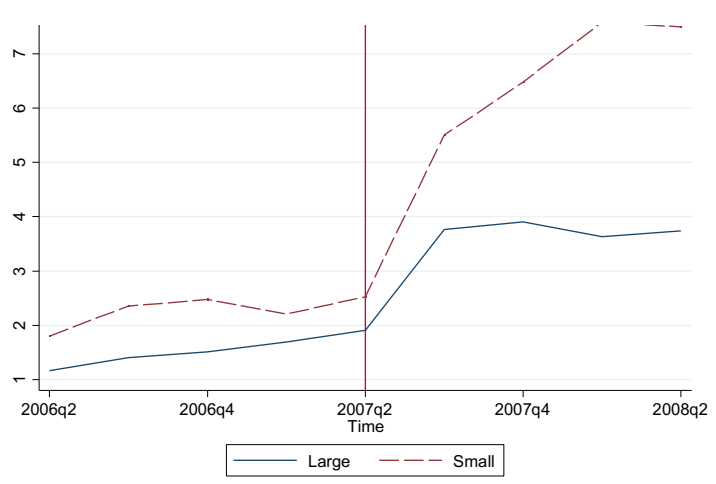

Panel B. Collateral vs Non-Collateral

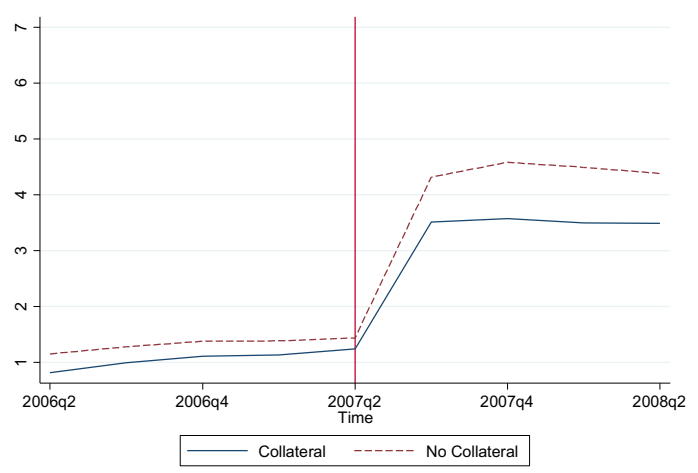

\section{Panel C. Higher Risk vs Lower Risk}

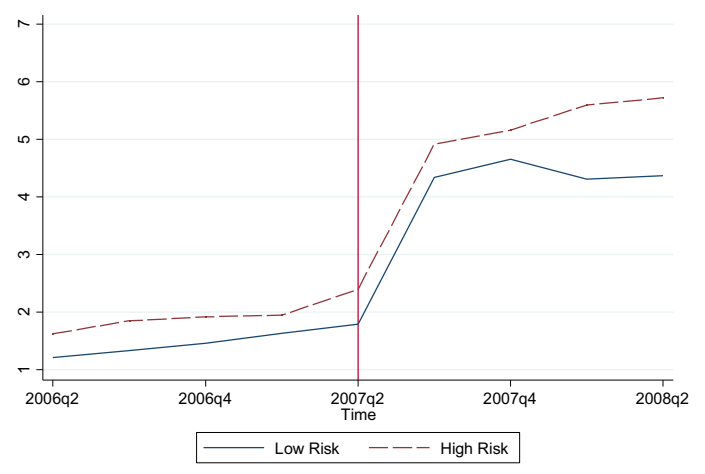




\section{Figure 2. Credit Margins}

The figure displays the coefficients $\beta_{q}$ estimated from the following regression conducted at the loan-level (i.e., bank-firm-quarter) including four quarters immediately before and after the implementation of the new provisioning scheme (i.e., from 2006Q2 to 2008Q2):

$$
y_{f, b, q}=\alpha+\sum \beta_{q} \text { Quarter }_{q} * \text { Smallfirm }_{f}+\gamma_{f, b}+\gamma_{b, q}+\varepsilon f b, q
$$

where $y_{f, b, q}$ is one of the following loan-level variables for firm $f$, bank $b$, and quarter $q$. Provisionsff, $q$ is the fraction of provisions to loan value (Panel A), Valuef,b,q is the log of loan value (measured in pesos) (Panel B), Interest Ratef,b,q is the loan interest rate (measured in percent) (Panel C), Maturity $f, b, q$ is the log of loan maturity (measured in years) (Panel D). Quarter $q$ is an indicator for quarter $q$. Smallfirm $f$ is an indicator variable for whether the firm is the smaller group. $\gamma_{f, b}, \gamma_{b, q}$ are firm-bank and bank-quarter fixed effects, respectively. We exclude the quarter prior to the implementation of SARC-2007Q2 - so that all coefficients of interest are estimated relative to that quarter. Standard errors are double-clustered at the firm-bank and quarter level. The vertical bar in all panels includes the quarters around the implementation of SARC. Standard errors are double clustered at the firm-bank and quarter level. The vertical bars display the 95 percent confidence levels.

Panel A. Provisions

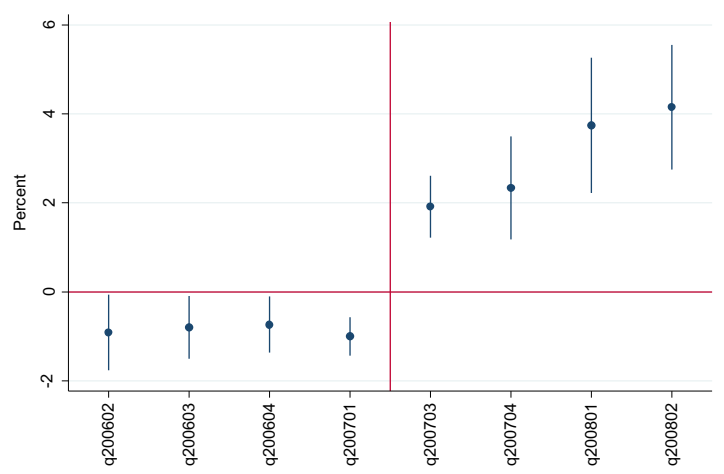

Panel C. Interest Rate

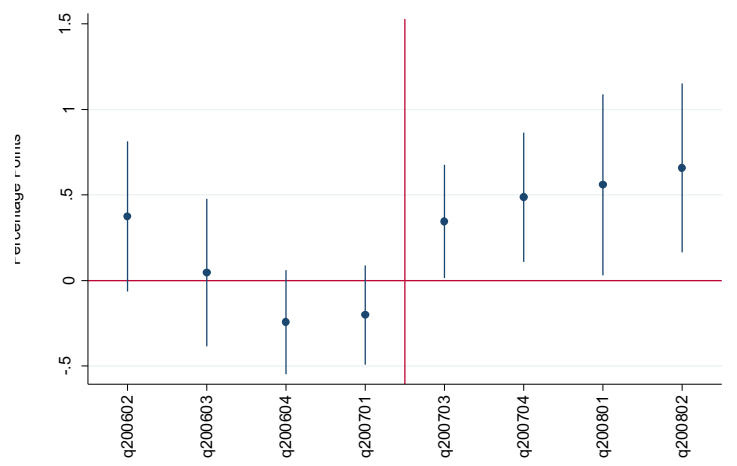

Panel B. Volume

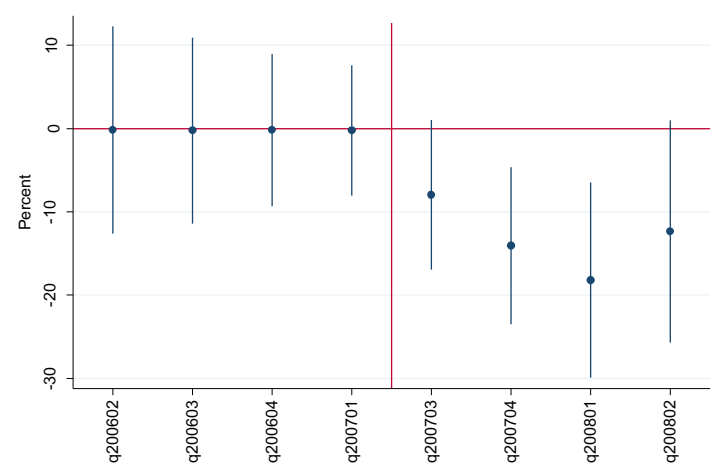

Panel D. Maturity

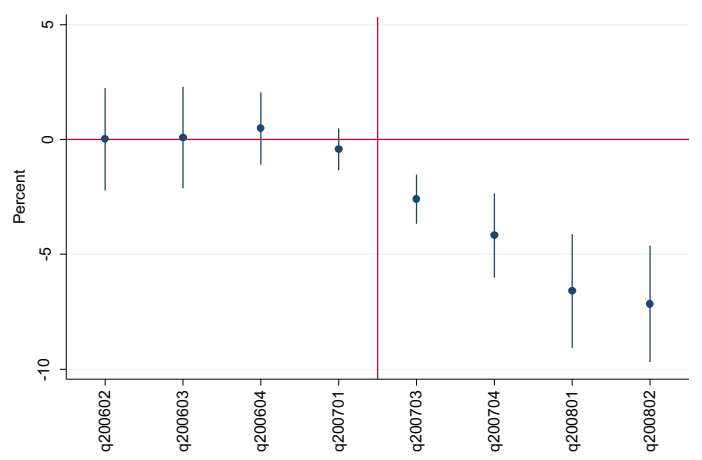




\section{Appendix}

\section{Table A1. Variable Definitions}

\section{$\underline{\text { Loan-Level Variables }}$}

Provisions $f, b, q$

Small Firm $_{f, q}$

Value $f, b, q$

Interest Rate $f, b, q$

Maturity $f, b, q$

Collateral $_{f, b, q}$

Latef,b,q

Default $_{f, b, q}$

Low- (High-)

Yield Borrowerf,b,q

Firm-Level Variables

Loansf,y

Assetsf,y

Liabilities $f, y$

Salesf,y

$\underline{\text { Sector-Level Variables }}$

Tangible Sectors

"Lower Risk Sectors" ("Higher Risk Sectors")
Fraction of provisions of the outstanding loans that firm $f$ holds from bank $b$ in quarter $q$, weighted by loan value (percent).

Indicator of whether firm $f$ is "small" according to the Superintendencia Financiera de Colombia, prior to the announcement of the reform. It depends on the wage bill of the firm and number of employees.

Value of the outstanding loans that firm $f$ holds from bank $b$ in quarter $q$ (thousands of Colombian pesos) (in Logs).

Average annualized loan rate of the outstanding loans that firm $f$ holds from bank $b$ in quarter $q$, weighted by loan value (percent).

Average maturity in years of the outstanding loans that firm $f$ holds from bank $b$ in quarter $q$, weighted by loan value (in Logs).

Percentage of loan value (to firm $f$ from bank $b$ at quarter $q$ ) covered by guarantees.

Indicator variable that equals one if a loan (to firm $f$ from bank $b$ at quarter $q$ ) is in arrears, and zero otherwise.

Indicator that a loan that firm $f$ holds from bank $b$ in quarter $q$ is more than 90 days in arrears, and zero otherwise.

A borrower-bank-quarter observation is low (high) yield if its average interest rateweighted by loan value - prior to the reform is below (above) the average of the quarter.

Total bank loans of firm $f$ in a year $y$ (thousands of Colombian pesos) (in Logs).

Total firm assets of firm $f$ in a year $y$ (thousands of Colombian pesos) (in Logs).

Total liabilities of firm $f$ in a year $y$ (thousands of Colombian pesos) (in Logs).

Total operational revenue of firm $f$ in a year $y$ (thousands of Colombian pesos) (in Logs).

Indicator variable that equals one if the tangibility ratio of sector $s$-measured as the average ratio of fixed assets to total assets - is above the sample median, and zero otherwise.

A sector is low (high) risk if average rate of loans in arrears is below (above) the median. 
Table A1. Variable Definitions

Bank-Level Variables

InsolvencyRisk $k_{b, q}$

Loans $b, q$

TangibilitySectorb, $q$

RiskSector,$q$

CreditHistoryb,q

Herfindahl Firmsb,q

Herfindahl Sector $b, q$
$(-1)^{*}$ Solvency $y_{b, 07 Q 2}$, where Solvency $y_{b, 072}$ is the solvency ratio of the bank in $2007 \mathrm{Q} 2$ (i.e., the quarter prior to the implementation of new provision scheme), computed as the ratio of tier 1 capital to risk-weighted-assets (percent).

Total value of outstanding loans for bank $b$ in quarter $q$ (in Logs).

Average tangibility (measured as the ratio of fixed assets to total assets) of the sectors of bank $b$ 's borrowers in quarter $q$ (percent).

Weighted average rate of defaulted loans (i.e., loans in arrears for more than 90 days) of the sectors of bank $b$ 's borrowers in quarter $q$ (percent).

Average years of bank's credit relation with its borrowers, weighted by loan value (in Logs).

Herfindahl index of the borrowers in a bank's lending portfolio in a quarter. The index is computed as the sum of the squares of the shares of the borrowers in the portfolio of loans (the share of a borrower in the portfolio is computed as the value of the loans to that borrower divided by the aggregated value of the loans in the portfolio)

Herfindahl index of the sectors of the borrowers of a bank's lending portfolio in a quarter. The index is computed as the sum of the squares of the shares of the sectors in the portfolio of loans (the share of a sector in the portfolio is computed as the value of the loans to borrowers in that sector divided by the aggregated value of the loans in the portfolio) 
Table A2 - Tangibility of Assets per Sector

This table displays the description of the top- and bottom-10 three-digit ISIC Rev3 sectors ordered by tangibility. Tangibility is defined as the ratio of fixed assets to total assets.

\begin{tabular}{|c|c|c|c|c|c|}
\hline \multicolumn{3}{|c|}{ Lowest } & \multicolumn{3}{|c|}{ Highest } \\
\hline Sector & Description & Tangibility & Sector & Description & Tangibility \\
\hline 803 & Higher education & 0.008 & 323 & $\begin{array}{l}\text { Manufacture of television and radio } \\
\text { receivers }\end{array}$ & 0.799 \\
\hline 243 & Manufacture of man-made fibers & 0.018 & 142 & Mining and quarrying & 0.798 \\
\hline 321 & $\begin{array}{l}\text { Manufacturing electronic valves and } \\
\text { tubes }\end{array}$ & 0.025 & 353 & $\begin{array}{l}\text { Manufacture of aircraft and spacecraft } \\
\text { Manufacture of refined petroleum }\end{array}$ & 0.484 \\
\hline 753 & Compulsory social security activities & 0.026 & 232 & products & 0.339 \\
\hline 912 & Activities of trade unions & 0.031 & 311 & Manufacture of electric motors & 0.336 \\
\hline 231 & Manufacture of coke oven products & 0.032 & 605 & Transport via pipelines & 0.323 \\
\hline 456 & $\begin{array}{l}\text { Renting of construction or demolition } \\
\text { equipment }\end{array}$ & 0.042 & 853 & Social work activities & 0.312 \\
\hline 990 & Extra-territorial organizations and bodies & 0.056 & 269 & $\begin{array}{l}\text { Manufacture of non-metallic mineral } \\
\text { products }\end{array}$ & 0.308 \\
\hline 732 & R\&D on social sciences & 0.063 & 410 & distribution of water & 0.302 \\
\hline 191 & Tanning and dressing of leather & 0.080 & 622 & Non-scheduled air transport & 0.302 \\
\hline
\end{tabular}


Figure A1. Macroeconomic Conditions Around the Period of the Reform
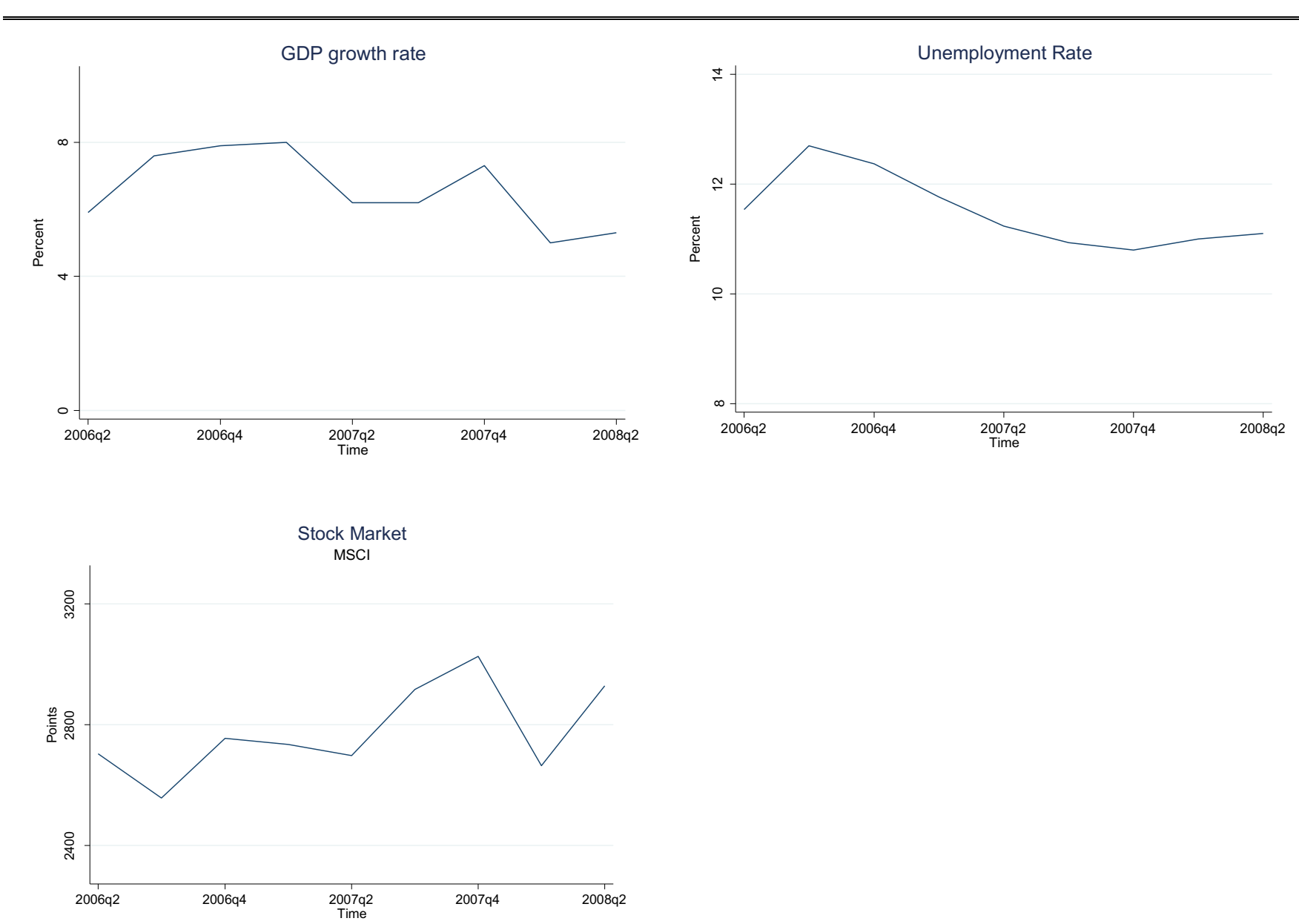